\title{
Revised manuscript with no changes marked
}

This is the author's version of a work that was accepted for publication in Tectonophysics (Ed. Elsevier). Changes resulting from the publishing process, such as peer review, editing, corrections, structural formatting, and other quality control mechanisms may not be reflected in this document. Changes may have been made to this work since it was submitted for publication. A definitive version was subsequently published in Domènech, $\mathrm{M}$, et al. "The inverted Triassic rift of the Marrakech High Atlas: a reappraisal of basin geometries and faulting histories" in Tectonophysics, vol. 663 (Nov. 2015), p. 177-191. DOI 10.1016/j.tecto.2015.03.017

1

2

3

4

5

6

7

8

9 Abstract

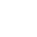

The inverted Triassic rift of the Marrakech High Atlas: a reappraisal of basin

geometries and faulting histories

Mireia DOMÈNECH ${ }^{a}$, Antonio TEIXELL ${ }^{a}$, Julien BABAULT ${ }^{a}$ and Maria-Luisa ARBOLEYA ${ }^{a}$

${ }^{a}$ Departament de Geologia, Edifici Cs, Avda. de l'Eix Central, Universitat Autònoma de Barcelona,

08193 Bellaterra (Barcelona, Spain)

${ }^{*}$ Corresponding author. Tel.: +34 5811163. E-mail address: mireia.geologa@gmail.com

The High Atlas of Morocco is an aborted rift developed during the Triassic-Jurassic and moderately inverted during the Cenozoic. The Marrakech High Atlas, with large exposures of basement and Triassic early syn-rift deposits, is ideal to investigate the geometries of the deepest parts of a rift, constituting a good analogue for pre-salt domains. It allows to unravel geometries and kinematics of the extensional and compressional structures and the influence that is exert over one another. A detailed structural study of the main Triassic basins and basin-margin faults of the Marrakech High Atlas shows that only a few rift faults were reactivated during the Cenozoic compressional stage in contrast to previous interpretations, and emphasizes that fault reactivation cannot be taken for granted in inverted rift systems. Preserved extensional features demonstrate a dominant dip-slip opening kinematics with strike-slip playing a minor role, at variance to models proposing a major strike-slip component along the main basin-bounding faults, including faults belonging to the Tizi n'Test fault zone. A new Middle Triassic paleogeographic reconstruction shows that the Marrakech High Atlas was a narrow and segmented orthogonal rift (sub-perpendicular to the main regional extension direction which was $\sim \mathrm{NW}-\mathrm{SE}$ ), in contrast to the central and eastern segments of the Atlas rift which developed obliquely. This difference in orientation is attributed to the indented Ouzellarh Precambrian salient, part of the West African Craton, which deflected the general rift trend in 
the area evidencing the major role of inherited lithospheric anisotropies in rift direction and evolution. As for the Cenozoic inversion, total orogenic shortening is moderate $(\sim 16 \%)$ and appears accommodated by basement-involved large-scale folding, and by newly formed shortcut and by-pass thrusting, with rare left-lateral strike-slip indicators. Triassic faults commonly acted as buttresses.

\section{Keywords}

Rift; Extensional fault; Rift inversion; Triassic; High Atlas; Morocco

\section{Introduction}

In the early stages of Pangea fragmentation in Triassic times a rift system propagated along the eastern North America-West Africa margin (the Atlantic rift), along the Africa-Europe margin (the Tethys rift), and in NW Africa (Fig. 1). The Atlas rift reached its maximum extent in mid Jurassic times, ceased in the late Jurassic, and was affected in Cenozoic times by AfricaEurope convergence, which led to the inversion of the rift (Choubert and Faure-Muret, 1962; Mattauer et al., 1977). In Morocco, the Atlas rift experienced moderate inversion and shortening strain (Teixell et al., 2003), which is least in the western segments of the chain (Frizon de Lamotte et al., 2000), in spite of high mean elevation. In consequence, large exposures of basement and early syn-rift Triassic deposits occur in the High Atlas of Marrakech (Fig. 2).

Such conditions make the Marrakech High Atlas an ideal area to investigate the evolution of a rift, which provides the uncommon opportunity to observe field analogues of pre-salt structures in early rift deposits (e.g., Karner and Gamboa, 2007). These are often obliterated due to strong inversion in field cases (e.g., Amilibia et al., 2008; Gillcrist et al., 1987; McClay et al., 1989), or poorly imaged in seismic data. At the same time, exposures in the Marrakech High Atlas permit the detailed study of the geometry and kinematics of extensional and compressional structures and the influence they exert over one another. 
Numerous studies have been carried out concerning the Triassic rift basins of the Marrakech High Atlas, including discussions on the main opening mechanisms. Even so, the principal structural aspects are still controversial. Among these is the contrasting interpretation of the main fault kinematics during the rifting stage, viewed as dip-slip (Baudon et al., 2009; El Arabi et al., 2003; Qarbous et al., 2003; Stets and Wurster, 1982; Van Houten, 1977) or strike-slip (Beauchamp, 1988; Laville and Petit, 1984; Laville and Pique, 1991; Laville et al., 2004; Mattauer et al., 1977; Ouanaimi and Petit, 1992). The role played by inherited basement anisotropy (e.g., Precambrian massifs and Variscan faults and folds, see Fig. 2) in the rift development and inversion is also debated (e.g., Laville and Pique, 1991; Missenard et al., 2007). A much debated structure is the so-called Tizi n'Test fault (Fig. 2a), a Triassic basinbounding fault defined as a major structure almost $280 \mathrm{~km}$ long inherited from at least Paleozoic times, and interpreted with strike-slip or dip-slip kinematics during the Mesozoic extension and/or the Cenozoic compression (Amrhar, 2002; Binot et al., 1986; Delcaillau et al., 2011; Froitzheim et al., 1988; Jenny, 1983; Laville and Pique, 1991; Laville et al., 2004; Mattauer et al., 1977, 1972; Proust et al., 1977; Qarbous et al., 2008, 2003).

With the purpose of shedding light on these controversial points, this study documents fault and basin geometries of Triassic basins from the Marrakech High Atlas, bordered by the Tizi n'Test fault (Fig. 2). We have emphasized the distinction between extensional and compressional structures and between dip-slip and strike-slip kinematics. Due to the modest inversion of the rift and to the exceptional preservation of rifting structures, a new paleogeographic reconstruction of the Marrakech High Atlas to the Triassic is presented. The study examples constitute good analogues for the deep parts of the Atlas rift, buried under thick Jurassic sediments in the remainder of the Atlas mountains, and in general for the exploration of deep rift basins.

\section{Geologic setting}

The Marrakech High Atlas has a dominant ENE-trend and can be subdivided into (1) an Axial Zone, characterized by large areas of Precambrian to Paleozoic basement exposure and numerous Triassic basins bounded by NE- to ENE-trending faults, and (2) the foothills, 
characterized by Cretaceous to Cenozoic post-rift to syn-inversion deposits, unconformable over basement or Triassic, and affected by thrust faults and folds with an E to ENE orientation (Fig. 2b).

The Marrakech segment of the High Atlas is located between the Moroccan Meseta to the north and the West African Craton (the Anti-Atlas range and the Ouzellarh salient; Choubert, 1952) to the south (Fig. 2a), areas which correspond to Precambrian and Paleozoic basement massifs that were relatively stable domains during the Mesozoic and Cenozoic deformation events. The Moroccan Meseta is characterized by detrital and carbonate rocks of Paleozoic age, strongly affected by Variscan deformation and low grade metamorphism. The Variscan grain trends mainly NNE-SSW, markedly oblique to the post-Paleozoic structures. The AntiAtlas, made up of Precambrian granites and andesites/rhyolites deformed by the Pan-African orogeny and onlapped by Lower Paleozoic sedimentary rocks, was only mildly deformed during the Variscan orogeny showing a general WSW-ENE trend of thrusts and folds (Choubert and Faure-Muret, 1962; Froitzheim et al., 1988; Hoepffner et al., 2005; Mattauer et al., 1972; Michard et al., 2010; Pique and Michard, 1989). The boundary between the two domains is poorly defined; some authors identified it as the Tizi n'Test fault (Fig. 2a), acting as a right-lateral strike-slip fault during the Variscan orogeny (Hoepffner et al., 2005; Mattauer et al., 1972), while for others the boundary is diffuse and not defined by the fault in all its length (Michard et al., 2010; Ouanaimi and Petit, 1992). Whatever the precise trace of the Variscan boundary, we will see that the rheological contrasts between the folded Paleozoic domain and the rigid Precambrian blocks such as the Ouzellarh salient played a major role on the geometry and location of the Triassic rift and the subsequent Cenozoic thrust belt.

After the Variscan orogeny, the NE- to ENE-trending Triassic-Jurassic Atlas rift developed (Fig. 1) linked with the Atlantic and Tethys opening (Choubert and Faure-Muret, 1962; Manspeizer et al., 1978; Van Houten, 1977). In the Marrakech High Atlas, preserved syn-rift Triassic sediments consist of red beds capped by volcanics (Beauchamp, 1988; Manspeizer, 1982), with an intervening diapiric evaporite layer evidenced in the Atlantic margin and in the Central High Atlas (Courel et al., 2003; Hafid et al., 2006; Saura et al., 2013; Tari et al., 2000). The up to $5000 \mathrm{~m}$ succession of syn-rift Jurassic carbonates and shales preserved in the 
Central and Eastern High Atlas of Morocco (Choubert and Faure-Muret, 1962) is almost absent in the High Atlas of Marrakech due to erosion during the Neogene (Balestrieri et al., 2009; Missenard et al., 2008), or to an originally poor development of the Jurassic rift there (as suggested from the progressive thinning of the Jurassic towards the W; Choubert and FaureMuret, 1962).

As for the rift development, two different rifting mechanisms have been proposed. Those advocating strike-slip as the main tectonic regime during the Mesozoic, view the Triassic basins of the Marrakech High Atlas as pull-apart basins limited by major left-lateral strike-slip faults oriented NE-SW to ENE-WSW, the most important being the Tizi n'Test fault (Beauchamp, 1988; Laville and Petit, 1984; Laville and Pique, 1991; Laville et al., 2004; Mattauer et al., 1977, 1972; Ouanaimi and Petit, 1992; Proust et al., 1977). On the contrary, those supporting a pure extensional regime (Baudon et al., 2009; El Arabi et al., 2003; El Kochri and Chorowicz, 1996; Qarbous et al., 2003; Stets and Wurster, 1982; Van Houten, 1977) view the main basin-bounding faults as dominantly dip-slip structures, including the Tizi n'Test major fault (Binot et al., 1986; Jenny, 1983).

The Triassic-Jurassic rifting stage was followed by a Cretaceous post-rift subsidence where sediments overfilled the rift troughs and unconformably covered the basement in the rift shoulders. Cenozoic inversion is characterized in the Marrakech area by thick-skinned tectonics with basement-involved thrust faulting and buckling either by the reactivation of former normal faults or by the formation of new structures (Froitzheim et al., 1988; Missenard et al., 2007). Again, the behavior of the Tizi n'Test fault during the Cenozoic inversion has been the subject of diverse interpretations: a thrust-reactivated fault (Binot et al., 1986; Froitzheim et al., 1988; Laville et al., 1977; Proust et al., 1977; Qarbous et al., 2003), a leftlateral strike-slip fault (Amrhar, 2002; Mattauer et al., 1977), or a still-active right-lateral fault (Delcaillau et al., 2011). Total orogenic shortening values in the Moroccan High Atlas are moderate, and decreasing from $E$ to $W$ (Teixell et al., 2003). In spite of this, the mean topographic elevations are high, and the highest summits are concentrated in the Marrakech High Atlas. A late Cenozoic mantle-driven thermal contribution to surface uplift has been 
isostatic anomaly in the Atlas chains and plateaux (Ayarza et al., 2005; Babault et al., 2008; Missenard et al., 2006; Teixell et al., 2003; Teixell et al., 2005; Zeyen et al., 2005), although due to its small width ( $\sim 40-60 \mathrm{~km})$, the high elevation of the Marrakech High Atlas cannot be explained by the mantle component, which would affect areas of over hundreds of $\mathrm{km}$.

\section{Triassic basins in the Marrakech High Atlas}

There are five main Triassic basins preserved in the High Atlas of Marrakech. From southwest to northeast they are the Tirknit, Tizi n'Test, Tizi n'Tacht-Imlil and Ourika basins (Fig. 2b). South of the Toubkal massif, there is the Eç Çour basin (Fig.2a). This study focuses on the Tirknit, Tizi n'Test and Tizi n'Tacht-Imlil basins, limited to the south by the Tizi n'Test fault.

Recent accounts of the Eç Çour and Ourika basins (Fig. 2) (Baudon et al., 2009; El Arabi et al., 2003) characterized both basins as controlled by two main fault trends: N70 and N20-45. The N70 faults controlled the basin opening and were interpreted as normal faults during the Triassic. Facies analysis of the clastic sediments suggests that these two basins were open to the east (i.e., connected to the Tethys) although separated from each other by the Ouzellarh salient. The tectonic significance of the southern border of the Ourika basin, which comprises the continuation of the Tizi n'Test fault zone, is reexamined in the present study (Fig. 2).

The Tirknit and Tizi n'Test Triassic basins (Fig. 2b) were also the subject of previous studies (Petit and Beauchamp, 1986; Qarbous et al., 2003), where the main structural elements were identified and a series of Triassic stratigraphic units were defined. A reappraisal of the significance of these basins is presented in the following sections, together with a new detailed study of the Tizi n'Tacht-Imlil basin.

The Triassic units consist of red clastic deposits with strong thickness variations controlled by syn-sedimentary faults. Detailed stratigraphic studies were reported in previous publications (Beauchamp, 1988; Benaouiss et al., 1996; Biron, 1982; Mattis, 1977; Petit and Beauchamp, 1986; Qarbous et al., 2003). Together with the Permian, which crops out in the Argana and Ourika basins (Fig. 2a) out of the study area, six stratigraphic units (F1 to F6) have been defined which can be correlated on the scale of the whole Marrakech High Atlas. The upper 
four units are Triassic in age and crop out in the study area (Fig. 3). From base to top, these are: (1) a Basal Conglomerate (F3), interpreted as proximal to distal alluvial fan deposits, 10 to $100 \mathrm{~m}$ thick, (2) the Ramuntcho Siltstone (F4), deposited in a tidal-flat environment and 60 to $120 \mathrm{~m}$ thick, (3) the fluvial Oukaimeden Sandstone (F5), divided into two subunits, the F5a or Purple subunit, 300 to $400 \mathrm{~m}$ thick, which contains intercalations of siltstone, and the F5b or Pink subunit, made of massive sandstones, $200 \mathrm{~m}$ thick, and (4) the Upper Siltstone (F6), more than $500 \mathrm{~m}$ thick, which contains gypsum and halite of alluvial plain to lagoonal origin, the upper limit of which is eroded. Palynological content dates the Ramuntcho Siltstone as Anisian (El Arabi et al., 2006) and the Pink Oukaimeden Sandstone as Carnian (Biron and Courtinat, 1982; Cousminer and Manspeizer, 1976). The Upper Siltstone is elsewhere overlain by tholeiitic basalts of the Central Atlantic Magmatic Province that yield Late Triassic to Early Liassic ages (Bertrand and Prioton, 1975; Courtinat and Algouti, 1985; Manspeizer et al., 1978). In the study area, F3, F4 and F5a are always limited by faults while F5b and F6 are either limited by faults or lie unconformably on basement. The thicknesses reported above (also shown in Fig. 3) correspond to the example thickness of the units in the western part of the Tizi n'Test basin (see Fig. $4 \& 5$ d). The distribution and approximate thickness variations of the different stratigraphic units are illustrated in cross sections of Figures 5 and 7.

\section{Structural analysis of the Triassic basins}

We have carried out a detailed analysis of the main structural features of three of the main Triassic basins, the Tirknit, the Tizi n'Test, and the Tizi n'Tacht-Imlil basins, and of the small Setti Fadma Triassic graben south of the Ourika basin (Fig. 2b). The structures have been classified on the basis of their role during the Triassic rifting and the Cenozoic compression. For the sake of clarity, the main faults in the study areas have been labelled by numbers. Arabic numbers indicate faults active during the rifting stage, whereas roman numbers denote faults active during the inversion (e.g., Fig 4). 


\subsection{Preserved extensional structures}

191

192

193

194

195

196

197

198

199

200

201

202

203

204

205

206

207

208

209

210

211

212

213

214

215

216

217

\section{Tirknit and Tizi n'Test Triassic basins}

The Triassic stratigraphic units (F3 to F6) of the Tirknit and Tizi n'Test basins are bounded to the south by high-angle faults belonging to the Tizi n'Test fault zone (faults 1 to 5 in Fig. 4). Faults 1 to 5 strike N60 to N70, downthrow the NW block and dip steeply (from 70N NW to subvertical) (Fig. 5). However, the original dip value of fault planes in the rifting stage cannot be generally determined with accuracy due to possible steepening during the compressional stage.

In the Tirknit basin, fault 1 (called Tirknit fault in Qarbous et al., 2003) was the rift border at least during sedimentation of the Basal Conglomerate (F3) and the Ramuntcho Siltstone (F4), as a few hundred meters to the south the Cretaceous post-rift deposits lie unconformably on basement (Fig. 4 \& 5a,b). In the Tizi n'Test basin, the F3 Triassic unit increases progressively its thickness to the south towards fault 4 and onlaps the basement to the NW defining a halfgraben. The F4 unit also increases in thickness to the south, but it is limited to the NW and SE by faults 4 and 6 respectively, defining a graben (Fig. $4 \& 5 d$ ). The F5a subunit is bounded by fault 4, and F5b overlaps to the NW, conforming again to a half-graben geometry (Fig. 5d,e,f). Along the basin axis, units also show marked thickness variations: F3 to F5a units thin and onlap from SW to NE (i.e, from the Tirknit to the Tizi n'Test basin, see Fig. 4 \& 5a-d). This indicates fault propagation to the NE, and is consistent with SW directed paleocurrents (Petit and Beauchamp, 1986) suggesting a basin deepening to the SW.

The Triassic formations adjacent to the main southern faults (faults 1 to 5 in Fig. 4) located in the hanging wall are folded into minor synclines $0.2-1 \mathrm{~km}$ in wavelength (e.g., the drag folds adjacent to normal faults 4 and 5 in Fig. $5 \mathrm{~d}$ and to fault 5 in Fig. 6a). Synclines are strongly asymmetric with a steeply-dipping forelimb (occasionally subparallel to the fault's strike and dip), and a gently-dipping backlimb. Synclinal axes run sub-parallel and close to the faults and en-echelon patterns are not observed (Fig. 4). Due to their local extent they can be ascribed to drag or extensional fault-propagation folding. In line with this, a footwall anticline of $\sim 1.8 \mathrm{~km}$ in wavelength is observed in the Paleozoic rocks adjacent to fault 5 (Fig. 6a) that because of its 
fault-parallel orientation (Fig. 4) we ascribe to Triassic faulting. Folds in Triassic units are consistent with a dip-slip extensional movement along the main faults and a minor reactivation during the compressional stage. This conclusion is reinforced by the attitude of a foliation observed in the shear zone in fault 5 (Fig. 6d), which is developed in Paleozoic slates close to the fault. Therefore, faults 1 to 5 belonging to the Tizi n'Test fault zone can be interpreted as normal faults not reactivated in the later compressional stage. Qarbous et al., (2003) interpreted the drag/fault-propagation folds as formed during the compression and the faults 1 to 5 as part of a NW-directed backthrust system, an interpretation which is not consistent with our observations since it would require these backthrust to have experienced a rotation to its current orientation, which is neither paralleled by the bedding in the adjacent fault blocks nor consistent with the potential steepening expected from the shortcut thrust II existing to the SE (Fig. 5d,e,f).

These major extensional faults are linked by relay ramps (e.g., the relay between faults 1 and 2 in Fig. 4), or by antithetic normal faults (e.g., the minor fault that links the normal faults 4 and 5, Fig. $4 \& 5 d$ ), which are consistent with extensional faulting kinematics in Triassic times. Minor syn-sedimentary intra-basin normal faults are common in the Triassic layers (Fig. 4 \& 6b), and were reported, in the Tizi n'Test basin, by Petit and Beauchamp (1986).

\section{Tizi n’Tacht-Imlil Triassic basin}

Fault 7 forms the northern limit of the Tizi n'Tacht basin (Fig. 7). The fault trends NE-SW and dips from $60^{\circ} \mathrm{SE}$ to (only locally) subvertical, and was the active rift margin during the accumulation of F4 and F5, as deduced from the rapid thickening of these units towards the fault, and also because $\mathrm{N}$ of fault 7, unit the F6 lies unconformable on basement. This fault keeps its normal throw in its western segment, where extensional drag/fault-propagation folds are locally observed (Fig. 8c). To the NE, the fault merges with short-cut thrust VIII (the resultant composite fault called Sidi Fars fault in Fig. 7), and it was thus reversed during the inversion stage.

244 The Triassic infill of the Tizi n'Tacht basin thickens to the NE, and in parallel, it overlaps to the 245 SW (e.g., F5b unit lies directly on basement in the Tisgui outcrop, see Fig. 7). This indicates a 
main basin opening and increased fault throw towards the NE, in agreement with the much thicker Ourika Triassic basin found in this direction (see summary above) (Baudon et al., 2009, and references therein), where NE-directed paleocurrents were reported (Fabuel-Perez et al., 2009).

251 The small, isolated Setti Fadma Triassic graben (Fig. 9) is located south of the Ourika basin.

252 We refer to Baudon et al. (2009) and Fabuel-Perez et al. (2009) for more information about the 253 main Ourika basin (see a summary above). The Setti Fadma graben is limited to the south by

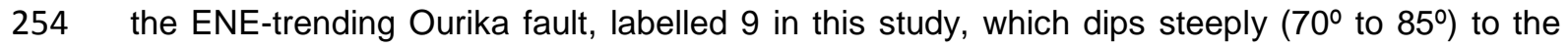
255 NNW. A northern, minor fault bordering the graben and trending sub-parallel to fault 9 is $\sim 70^{\circ}$ 256 dipping to the SE. Triassic beds define a syncline (Fig. 9), strongly dragged in the proximity of 257 faults. The Precambrian basement is largely preserved in the area and consists of granodiorites intruded by minor mafic dykes, which are present in the footwall but not in the hanging wall of fault 9 (Fig. 9). Dykes are NNE-SSW striking and nearly vertical, and in plan

260 view, no progressive change on orientation into the fault 9 proximity (i.e., by shearing) is observed (Fig. 9).

\subsection{Compressional structures}

263 Although the distortion of the Triassic rift structures of the Marrakech High Atlas has been relatively modest during the Atlas mountain building, a series of compressional features can be identified, consisting mainly in shortcut thrusts and large-scale folds, fault reactivation being limited.

Tizi n'Test and Tirknit basins

South of the Tizi n'Test and Tirknit basins, faults I and II (Fig.4) can be understood as shortcut thrusts formed in the footwall of the main extensional faults ( 1 to 5 faults) during the Cenozoic inversion stage. These thrusts carry basement over the Cretaceous post-rift deposits (Fig. 4 \& $5 a, d)$. Shortcut thrust II dips $30^{\circ}-40^{\circ}$ to the NNW. It merges with fault 1 by a lateral ramp east 
of Tirknit (Fig. 4). The minor shortcut thrust I (Fig. 4), dipping $\sim 40^{\circ}$ to the NNW, dies out laterally. Cretaceous and Tertiary rocks south of shortcut thrusts are affected by basementinvolved WSW-ENE to E-W folds and thrusts and by minor folds linked with intra-Cretaceous decóllement levels (Fig. 4 \& 5a). Intra-Cretaceous folds were progressively rotated and cut by the lateral ramp of thrust II (e.g., $3 \mathrm{~km}$ to the SW of Takalilt, Fig. 4), which indicates that the thrust moved at a late stage, being out-of-sequence. On the other hand, thrust II separates two distinct basement domains, with the Paleozoic strongly affected by Variscan folds, thrusts and low-grade metamorphism in the hanging wall, whereas the footwall Paleozoic strata are only slightly affected by the Variscan orogeny (Moroccan Meseta and Anti-Atlas domains respectively, Angoud et al., 2002). These clearly differentiated pre-Triassic domains indicate that thrust II may have reactivated a Variscan structure.

The Tizi n'Test basin is partitioned by a pop-up thrust block formed by thrusts $\mathrm{V}$ and VI, uplifting Paleozoic rocks (Fig. $4 \& 5$ d,e). Thrust V (called Tadafelt thrust by Qarbous et al., 2003), is here interpreted as a neoformed by-pass thrust within the basin, due to its gentle dip and because the thickness of the Triassic units is similar across it, at variance with Petit and Beauchamp (1986) and Qarbous et al. (2003), who described it as a reactivated normal fault. Also the northern thrust, fault VI (called Tinmel fault by Qarbous et al., 2003), is interpreted as a neoformed thrust fault due to its orientation, parallel to thrust $\mathrm{V}$, and to its gentle dip (Fig. $5 d, e)$. These thrusts strike E-W turning progressively into ENE-WSW close to normal fault 5 , and tipping out in the Upper Siltstone (F6 in Fig.4). Northwest of normal fault 5, backthrust VII also involves basement and shows a progressive dip variation, from gentle to steep, towards the NE, being subvertical near Talat-n-Ya'Qoub (Fig. 5f). We interpret backthrust VII and the map-view rotation of thrusts $\mathrm{V}$ and $\mathrm{VI}$ as produced by buttressing against the higher angle normal faults 4 and 5 .

In addition to thrusting, the Tizi n'Test and Tirknit Triassic basins were also affected by largescale folds which deform the basement and the Triassic cover alike, with apparently little mechanical contrast (Fig. 4 \& 5). These folds may indicate large-scale buckling processes in the Marrakech High Atlas, not related to observable thrust faults. The Tizi n'Test basin is folded into a major synform (5-6 km in wavelength), enhancing the tilting of the northern basin 
301

border (currently dipping $30^{\circ}$ to $60^{\circ}$ to the SE, Fig. 5e,f \& 6c), and possibly promoting the development of thrusts V, VI and VII as out-of-syncline thrusts in its core. This folding may be responsible of the local oversteepening of thrust VII. This deformation, together with shortcut thrusts I and II, is also responsible of the steepening of the major non-reactivated normal faults 1 to 5 to their present attitude (Fig. 5). A correlative antiform, developed north of the Tirknit basin, tilted Triassic beds of the northern part of the basin to their current 40 to $50^{\circ}$ dip (Fig. 5a); the NE plunge of this antiform combined with erosion caused the SW termination of the Tizi n'Test basin exposure (Fig. 4).

\section{Tizi n'Tacht-Imlil basin}

The Tizi n'Tacht basin and its border fault (fault 7 in Fig. 7) were transported NW by the shortcut thrust VIII. This shortcut thrust formed in the footwall of normal fault 7 and overrides Cretaceous post-rift deposits to the north (Fig. 7 \& 8a).

South and east of the Tizi n'Tacht area, the basin is affected by thrust IX, fault 8 and backthrust X (Fig. 7 \& 8a,b). Fault 8 (called Oukaimeden fault by Baudon et al., 2009) is interpreted as a normal fault reactivated with reverse movement (Baudon et al., 2009). Thrust IX and backthrust $X$ are in the continuation of the Tizi n'Test fault (Fig.2). Thrust IX dips gently to the SSE in the Tisgui area (Fig.7), increasing progressively in dip (to $60-80^{\circ}$ ) to the east (section a-a' in Fig. 7). The Triassic F5b subunit exposed in the thrust footwall lies directly on basement and is cut by the thrust in a low-angle ramp geometry (section a-a' in Fig. 7). The $X$ backthrust dips $70^{\circ}-80^{\circ}$ to the NW. The F6 Triassic unit is preserved in its footwall and dips steeply to the NNW, forming a footwall flat geometry (section b-b' in Fig. 7). Due to the structural relations described, thrust IX and backthrust $X$ cannot be considered as reactivated normal faults, but instead must have been formed during the compressional stage as new thrust faults. Both thrust faults are linked by a nearly vertical left-lateral transfer fault striking NW-SE (Fig. 7) with preserved strike-slip striae on the fault plane.

Backthrust $X$ presents two distinct striae directions, one nearly vertical (Fig. 8e) and other nearly horizontal (Fig. 8d) with a left-lateral sense of movement. Although the amount of exposed slickensides is not enough to make a population analysis, it seems clear that 
backthrust $X$ had two distinct phases of movement. In the same way, the few slickensides observed in the thrust IX indicate dip-slip, but Riedel fractures occasionally observed in the fault zone suggest a certain component of sinistral strike-slip.

A long-wavelength $(\sim 5 \mathrm{~km})$ antiform affects the whole Tizi n'Tacht basin (Fig. 7), separating the Triassic adjacent to faults IX, X and 8 from the main body of the Tizi n'Tacht basin. Again, this folding could be linked with large-scale buckling processes (not thrust-related), and could account for the present steep dip of thrusts IX and X (Fig. 7). These thrusts may have formed as gently-dipping, later steepened enabling the strike-slip movement indicated by scarce microstructures.

\subsubsection{Selective reactivation of normal faults}

In the Tizi n'Test and Tirknit basins a significant normal fault reactivation with reverse movement may have occurred only in the case of fault 1 because the elevation of the lower Triassic sequences with respect to the Cretaceous layers existing to the south (Fig. 5a) is too high to be explained by the shortcut thrust I, which has a minor displacement indicated by its limited lateral continuity (Fig. 4). However, the amount of reverse slip cannot be determined as the upper Triassic units of the Tirknit basin have been eroded and also because part of this higher altitude could be explained by the large antiform that affects the northern Tirknit basin (Fig. 5a). In addition, the preservation of extensional drag/fault-propagation folds suggests that reactivation was minor. A microstructural analysis of the fault zone was not possible as it is poorly exposed. Secondary faults within the Tizi n'Test basin such as normal fault 6 (Fig. 4 \& 5d) were reactivated in the compression stage. This fault, striking E-W and active during the sedimentation of the Ramuntcho Siltstone (F4) was reversed a few tens of meters and propagated into the Oukaimeden Sandstone (the thickness of this unit does not change across the fault), tipping out along strike into the Upper Siltstone unit (Fig. 5d). (Oukaimeden fault; Baudon et al., 2009) and Sidi Fars fault (Fig. 7). 
To complete the inferences from large-scale structures we undertook a kinematic analysis of the main fault zones based on slickensides (Fig. 10). The Marrakech High Atlas has been the subject of earlier microstructural studies based on minor fault populations (Laville and Petit, 1984; Proust et al., 1977; Qarbous et al., 2003, 2008). A study by Qarbous et al. (2003) focused on fault populations within the Triassic basin fill (mainly the Oukaimeden Sandstone) indicated an intra-Triassic extensional regime. The stress fields obtained consist of a vertical maximum stress and a minimum stress oriented NW-SE to N-S (present-day orientations). The same conclusions had been earlier reported by Laville and Petit (1984), although fault plane data were not provided. Proust et al. (1977) reported conjugate NNE-SSW and NNWSSE strike-slip faults deducing a N- to NNW-trending compressional stress of uncertain age, which could be related to the Cenozoic inversion (see also Qarbous et al., 2008).

We focused our contribution on the major Triassic faults, at selected localities which provided a significant number of striated planes. These represent 3 of the 9 numbered faults mapped in Figures 4, 7 and 9. The fault zones, developed in siliceous basement rocks, contain minor striated fault planes, but sense-of-shear criteria are very scarce. The majority of striae are steeply-dipping to subvertical (Fig. 10). Of a total of 158 slickensides measured, 116 showed a pitch $>45^{\circ}$. On the absence of reliable sense-of-shear indicators, we cannot ascertain whether the highly pitching striated planes formed during Triassic rifting as normal faults or during the Cenozoic inversion as thrust faults, although, as discussed above, observations point to little

375 fault compressional reactivation at the macroscopic scale. Our results show two main families of striated fault planes, a dominant one with ENE-WSW to NE-SW direction, which corresponds to the main trend of the Tizi n'Test fault zone, and a second corresponding to fault planes striking from NNE-SSW to N-S (Fig. 10). Of those within the range of orientation of the Tizi n'Test fault zone, only 16 of them $(22 \%)$ show slikenlines pitching $\leq 45^{\circ}$. We thus conclude that the main kinematics recorded in the major fault zones of the study area is close to dip-slip, with a certain component of obliquity. 


\section{Discussion}

383

The Triassic basins of the Marrakech High Atlas have been traditionally associated with the major Tizi n'Test fault, reported as a continuous fault, dominating rift opening and later inversion. In this study we mapped $200 \mathrm{~km}$ of the $280 \mathrm{~km}$ long Tizi n'Test fault zone (Fig 2). The study shows that neither the basins nor the fault are continuous throughgoing features. Instead, the fault zone is highly segmented, and faults that controlled Triassic basin opening should be regarded as forming a wide deformation band across the Marrakech High Atlas with a ENE- to NE- trend. The band consists of half-grabens in the southwest (Tirknit and Tizi n'Test basins, Fig. 4), and a rather symmetric graben system limited by oppositely-dipping faults in the northeast (Tizi n'Tacht-Imlil and Ourika basins, Fig. $7 \& 9$ ). The preservation of normal offsets and extensional minor structures indicate that during the Cenozoic inversion the main basin-bounding faults were not significantly reversed.

Of the 8 major rift faults of the study area that showed minor reactivation during the compression (faults 1 to 9 in Figs. $4,7 \& 9$; Fault 8 is not included due to their major reactivation), 7 were characterized by macrostructures (faults relays and fault-related folds), and 4 by mesostructures ( 3 by fault-plane populations and 1 by foliation), which indicate a dominant dip-slip movement along the main basin-bounding faults, possibly with a certain oblique-slip character. Although the absence of sense-of-shear indicators along the main rift faults is not indicative, folds and foliation observations favor a dominant extensional opening of the Triassic basins. Indeed, a number of strike-slip slickensides was observed (Fig. 10), consistently with the observations by Proust et al. (1977) and Qarbous et al. (2008) in the Triassic basin infill, but these were attributed to horizontal compression, and are of relative minor significance in the main faults analysed here. We cannot support the common view of the Tizi n'Test fault zone as a major strike-slip/transform fault system, and the Triassic basins as formed by pull-apart mechanisms.

Diverging paleocurrents and onlap patterns observed in the Triassic deposits indicate that the Tirknit-Tizi n'Test and Tizi n'Tacht basins were separated by an intervening topographic high at the western end of the Ouzellarh salient (Toubkal massif in fig. 2) at least in early and mid- 
rifting stages (see the overlap of Lower Triassic units to the NE and SW in Fig. 4 and 7 respectively), at variance with previous reconstructions (Baudon et al., 2012; Frizon de

412 Lamotte et al., 2009; Laville et al., 2004) which assume a connection between the Tirknit-Tizi n'Test basins with the Tizi n'Tacht-Ourika ones. Squeezed Triassic remnants found to the south of the Tichka granite and between the Tichka granite and the Argana basin (Fig. 2b) suggest that the Tirknit-Tizi n'Test Triassic basins, which show paleocurrents to the SW (Petit and Beauchamp, 1986), could be connected to the Argana basin in the Atlantic margin as already proposed by Stets and Wurster (1981). Based on these observations we present a new reconstruction of the paleogeography of the Marrakech High Atlas rift (Fig. 11a) in mid Triassic times (prior to the deposition of the Carnian Pink Oukaimeden sandstone, F5b).

As shown above, during the Cenozoic compression the main basin-bounding normal faults were not significantly reversed, except in local cases such as fault 1, fault 8 and the northern margin of the Ourika basin (Sidi Fars reverse fault; fig. $7 \& 11$ b). The Atlas shortening was accommodated by newly-formed thrusts (shortcut and by-pass) and by more continuous deformation as evidenced by long-wavelength folding and steepening of normal faults by rotation, acting them as buttresses. Some left-lateral slip is expected in NE- to ENE- trending faults, which were oblique to the Cenozoic compression direction, generally assumed to be close to N-S in the Atlas (Mattauer et al., 1977). The minor subpopulations of oblique- to strike-slip striated planes in the major normal faults discussed earlier (Fig. 10) may represent this component. Evidence for a strike-slip component in the thrust faults is limited to only two near-vertical thrusts of the Tizi-n'Tacht area (thrusts IX and X, located in Fig. 7). Again, even though a transpressive character of the thrust faults cannot be discarded, we conclude that the strike-slip component during the Cenozoic compression is minor.

Figure 12 shows a present-day cross-section of the Marrakech High Atlas across the Tizi n'Test basin and a tentative restoration previous to the Cenozoic orogeny (see Fig. $2 \mathrm{~b}$ for location). The hanging wall cutoffs of some major Cenozoic thrusts are not observed, and thus the restoration has to rely on minimum displacement estimates and contains a significant degree of uncertainty. Jurassic sediments are not preserved under the Cretaceous of the 
data they have not been represented in the section, and the Cretaceous is drawn unconformable above the F6 Triassic unit. A comparison between the present-day and restored sections suggests a minimum amount of total shortening of $\sim 13 \mathrm{~km}(16 \%)$, which, in spite of the uncertainties, contrasts to the previous estimation by Missenard et al. (2007) indicating as little as $3 \mathrm{~km}$ of shortening in a section a few $\mathrm{km}$ to the east (across Sidi Rahal; see locality in Fig. 2a). The amount of shortening here estimated is consistent with previous works in Central and Eastern High Atlas which proposed values of total shortening of 30 to 13 $\mathrm{km}$, decreasing from east to west (Teixell et al., 2003).

\section{Fault localization and orientation}

Many previous authors assume that the major Triassic faults were inherited from Variscan structures (Baudon et al., 2009; El Arabi et al., 2003; Laville and Piqué, 1991; Laville et al., 2004; Proust et al., 1977). However, only in limited cases do the Triassic faults clearly follow Variscan structures, as for example, normal fault 1 and Sidi Fars fault (Fig. 4 \& 7), which mark a change in pre-Mesozoic geology (Variscan folding and metamorphism vs. mild deformation across fault 1, and Precambian vs. Carboniferous rocks across the Sidi Fars fault; Fig. 11). As for the rest of the main basin-bordering faults, their possible inherited character cannot be ascertained, as there are no changes in pre-Triassic geology across them. At a larger scale, a major feature controlling rifting in the Marrakech High Atlas and its transition to the Central High Atlas is the Ouzellarh Precambrian salient (Fig.2a \& 11). This salient, part of the West African Craton (Anti-Atlas domain), appears as a foreland uplift indented into the Variscan chain (see reconstructions in Michard et al., 2010). The Marrakech High Atlas rift is divided into three branches, the Ourika graben to the north, the Eç Çour basin to the SE and the Tizi n'Test to the SW. In between is the Toubkal horst (Fig. 11a). The Eç Çour basin terminates to the southwest towards the Ouzellarh salient, whereas the Ourika basin borders the massif to the north and narrows dramatically to the southwest, in the Tizi n'Tacht-Imlil basin (Fig. 11a).

464 The geological record of rift systems shows that continental break-up is not randomly distributed but tends to follow the trend of pre-existing weaknesses at lithospheric scale (e.g., ancient orogenic belts), avoiding stronger regions (e.g., cratons). Such lithospheric contrasts 
Corti, 2012 and references therein). The Mesozoic High Atlas rift follows a major lithospheric boundary between the Variscan chain and the West African Craton (Anti-Atlas). This boundary

470 is still expressed today by a marked contrast in seismic velocity at the lithospheric scale (e.g., Missenard and Cadoux, 2012). This major lithospheric feature may explain the oblique rift character of the Central and Eastern High Atlas rift, with margins trending N75-N80 and internal faults oriented N55-N60, perpendicular to the inferred extension direction (Arboleya et al., 2004; El Kochri and Chorowicz, 1996). However, our paleogeographic reconstruction (Fig. 11a) shows that the Triassic rift in the Marrakech High Atlas was narrow with margins trending NE-SW in average, that is, roughly orthogonal to the approximate NW-SE extension direction inferred for the Triassic and Jurassic (present-day orientations; Ait Brahim et al., 2002; El Arabi et al., 2003; El Kochri and Chorowicz, 1996; Hailwood and Mitchell, 1971; Laville and Petit, 1984; Laville and Piqué, 1991; Mattauer et al., 1977; Qarbous et al., 2003). The orthogonal character of this rift segment in contrast with the Central High Atlas may tell us that it roughly follows the transition zone between the Variscan chain and the West African craton, which was originally deflected due to the indentation of the Ouzellarh Precambrian salient. Moreover, temporal departures from the NW-SE prevailing extension direction during the rifting to an WNW-ESE direction as reported by Baudon et al. (2009) and Medina (1995) should not alter the dip-slip character of the main faults, as inferred today from modern oblique rift systems where measured stresses are perpendicular to the trend of the main faults irrespective of their obliquity to the regional, far-field extension (Morley, 2010) .

As for the localization of the Cenozoic contractional deformation, the Triassic faults of the Marrakech High Atlas were not the sites of major thrust reactivation, with the exception of the cases where these faults already reactivated previous Variscan faults, like fault 1 and Sidi Fars fault (Fig. 11b). In the Tizi n'Test basin area, thrust II marks the boundary between different Variscan domains (Angoud et al., 2002). Steep Triassic normal faults acted as buttresses, and thrusts formed instead as footwall shortcuts or by-passed them (e.g., fig. $5 d$ \& $6 e)$. In this segment of the Atlas chain, the major Cenozoic thrusts (thrust II, Medinat thrust, south and north Atlas mountain fronts; Fig. 11b) are out of the basin margin faults. Neither the 
497

498

499

500

501

502

503

504

505

506

507

508

509

510

511

512

513

514

515

516

517

518

519

520

521

522

523

524

(Fig. 11). These thrust fronts trend ENE-WSW; hence, the general ENE-WSW trend of the present-day Marrakech High Atlas belt (which is oblique to the Triassic faults) results from Cenozoic thrusting. Again, a marked influence is exerted by the Ouzellarh salient, as the Eç Çour thrust and thrust II die out or bend around the massif rather than crossing it (Fig. 11b), being the southern thrust front of the High Atlas very poorly defined in the massif itself.

\section{Conclusions}

The mild rift inversion and the erosion level of the Marrakech High Atlas, where large exposures of basement and Triassic syn-rift deposits exist, make it an ideal area to investigate the early stages of evolution of a rift and provide field analogues to pre-salt geometries in deep basins. This detailed study of the main Triassic basins and basin-margin faults of the Marrakech High Atlas shows that only a few rift faults were reactivated during the Cenozoic compressional stage, emphasizing that fault reactivation cannot be taken for granted in inverted rift systems. The location of the Triassic rift between the Moroccan Variscan chain and the West African Craton (Anti-Atlas and Ouzellarh Precambrian salient) indicates that previous lithospheric anisotropies played a crucial role on the localization of the deformation not only during the rifting stage but also during the later inversion.

A new Middle Triassic paleogeographic reconstruction shows that the Marrakech High Atlas was a narrow rift controlled by N60-trending margin faults. Basins developed roughly orthogonal to the general extension direction ( NE-SW in the present-day frame). The orthogonal character of this rift segment is interpreted as due to the indented Ouzellarh Precambrian salient, which deflected the Variscan chain and subsequently the general rift trend, at variance to the Central and Eastern High Atlas, which developed obliquely (ENEWSW) to the general extension direction. A complex system of Triassic horsts and grabens is here described, evidencing the segmented nature of the rift. Diverging paleocurrents and onlap patterns indicate that the Tirknit-Tizi n'Test and Tizi n'Tacht-Ourika basins were separated by an intervening high at least in early- and mid-rifting stages. Preserved extensional features (e.g., fault-propagation/drag folds, minor faults, slickenslides) show a dominant dip-slip or oblique-slip opening kinematics, in contrast with models proposing a 
major strike-slip component into the main basin-bounding faults, including faults belonging to the Tizi n'Test fault zone (which has been viewed as a major strike-slip/transform fault).

As for the Cenozoic inversion, shortening was accommodated by basement-involved largescale folding, and by shortcut and by-pass thrusting, with sparse evidence for left-lateral strikeslip, which could have taken place but was not a major component of the deformation. Triassic faults commonly acted as buttresses. In this segment of the High Atlas chain, the major Cenozoic thrusts are out of the basin margin faults and are associated to a modest amount of total orogenic shortening ( 16\%).

\section{Acknowledgements}

This work was supported by MEC projects CGL2010-15416, CGL2007-66431-CO2-01 (TOPOMED), and ConsoliderIngenio2010 CSD2006-00041 (TOPOIBERIA). Research by M. Domènech is funded by a predoctoral grant from Ministerio de Educación (España). We thank Eduard Saura for revision of the original manuscript and Raül Mas, Marc Viaplana, Andreu Badia and Anna and Mariano Medina for field assistance. The detailed comments by two anonymous referees are acknowledged. Cross sections were constructed with the software Move, provided by Midland Valley through the ASI program.

\section{References}

Ait Brahim, L., Chotin, P., Hinaj, S., Abdelouafi, A., El Adraoui, A., Nakcha, C., Dhont, D., Charroud, M., Sossey Alaoui, F., Amrhar, M., Bouaza, A., Tabyaoui, H., Chaouni, A., 2002. Paleostress evolution in the Moroccan African margin from Triassic to Present. Tectonophysics 357, 187-205. doi:10.1016/S0040-1951(02)00368-2

Amilibia, A., Sàbat, F., McClay, K.R., Muñoz, J. a., Roca, E., Chong, G., 2008. The role of inherited tectono-sedimentary architecture in the development of the central Andean mountain belt: Insights from the Cordillera de Domeyko. J. Struct. Geol. 30, 1520-1539. doi:10.1016/j.jsg.2008.08.005 
549

550

551

552

553

554

555

556

557

558

559

560

561

562

563

564

565

566

567

568

569

570

571

Amrhar, M., 2002. Paléocontraintes et déformations syn- et post-collision Afrique-Europe identifiées dans la couverture mésozoïque et cénozoïque du Haut Atlas occidental (Maroc). C.R. Geoscience 334, 279-285.

Angoud, M., Atik, M., Benchra, M., Cherifi, A., Daimi, A., Driouiche, H., El Houari, N., El Khlifi, A., El Maoukour, A., El Mouatani, A., Essafi, M., Labriki, M., Mimet, A., Yahyaoui, L., 2002. Carte géologique du Maroc, scale 1:50.000, sheet NH-29-XXIII-1c: Tafingoult. Ed. du Serv. Géologique du Maroc Notes Mémoires 444.

Arboleya, M.L., Teixell, A., Charroud, M., Julivert, M., 2004. A structural transect through the High and Middle Atlas of Morocco. J. African Earth Sci. 39, 319-327.

Ayarza, P., Alvarez-Lobato, F., Teixell, A., Arboleya, M.L., Tesón, E., Julivert, M., Charroud, M., 2005. Crustal structure under the central High Atlas Mountains (Morocco) from geological and gravity data. Tectonophysics $400,67-84$.

Babault, J., Teixell, A., Arboleya, M.L., Charroud, M., 2008. A Late Cenozoic age for longwavelength surface uplift of the Atlas Mountains of Morocco. Terra Nova 20, 102-107.

Balestrieri, M.L., Moratti, G., Bigazzi, G., Algouti, A., 2009. Neogene exhumation of the Marrakech High Atlas (Morocco) recorded by apatite fission-track analysis. Terra Nova 21, 75-82. doi:10.1111/j.1365-3121.2008.00857.x

Baudon, C., Fabuel-Perez, I., Redfern, J., 2009. Structural style and evolution of a Late Triassic rift basin in the Central High Atlas, Morocco: controls on sediment deposition. Geol. J. 44, 677-691. doi:10.1002/gj.1197

Baudon, C., Redfern, J., Van Den Driessche, J., 2012. Permo-Triassic structural evolution of the Argana Valley, impact of the Atlantic rifting in the High Atlas, Morocco. J. African Earth Sci. 65, 91-104. doi:10.1016/j.jafrearsci.2012.02.002 
572 Beauchamp, J., 1988. Triassic sedimentation and rifting in the High Atlas (Morocco), in: 573 Developments in geotectonics, 22, (Elsevier) (Ed.), Triassic-Jurassic Rifting. Manspeizer, $574 \quad$ W, pp. 477-497.

575 Benaouiss, N., Courel, L., Beauchamp, J., 1996. Rift-controlled fluvial/tidal transitional series 576 in the Oukaïmeden Sandstones, High Atlas of Marrakesh (Morocco). Sediment. Geol. 577

Bertrand, H., Prioton, J.M., 1975. Les dolérites marocaines et l'ouverture de l'Atlantique; étude 579 pétrologique et géochimique. Univ. Lyon.

Binot, F., Dresen, G., Stets, J., Wurster, P., 1986. Die Tizi-n' Test-Verwerfungszone im Hohen Atlas (Marokko). Geol. Rundschau 75, 647-664.

Biron, P., Courtinat, B., 1982. Contribution palynologique a la connaissance du Trias du HautAtlas de Marrakech, Maroc. Geobios 15, 231-235.

Biron, P.E., 1982. Le Permo-Trias de la région de l'Ourika (Haut Atlas de Marrakech, Maroc). Univ. Grenoble.

Choubert, G., 1952. Histoire géologique du domaine de l'Anti-Atlas. Notes Mémoires du Serv. géologique du Maroc 100, 196 pp.

Choubert, G., Faure-Muret, A., 1962. Évolution du Domaine Atlasique Marocain depuis les temps paléozoïques. Livre à la mémoire du Profr. Paul Fallot - Soc. Geol. Fr. 1, 447-

Corti, G., 2012. Evolution and characteristics of continental rifting: Analog modeling-inspired view and comparison with examples from the East African Rift System. Tectonophysics 522-523, 1-33. doi:10.1016/j.tecto.2011.06.010

Courel, L., Aït Salem, H., Benaouiss, N., Et-Touhami, M., Fekirine, B., Oujidi, M., Soussi, M., 595 Tourani, A., 2003. Mid-Triassic to Early Liassic clastic/evaporitic deposits over the 

Maghreb Platform. Palaeogeogr. Palaeoclimatol. Palaeoecol. 196, 157-176. doi:10.1016/S0031-0182(03)00317-1

Courtinat, B., Algouti, A., 1985. Caractérisation probable du Sinémurien près de Telouat (Haut Atlas, Maroc): datation palynologique. Geobios 18, 857-864.

Cousminer, H.L., Manspeizer, W., 1976. Triassic pollen date Moroccan High Atlas and the incipient rifting of the pangea as middle Carnian. Science 191, 943-945.

Delcaillau, B., Amrhar, M., Namous, M., Laville, E., Pedoja, K., Dugué, O., 2011. Transpressional tectonics in the Marrakech High Atlas: Insight by the geomorphic evolution of drainage basins. Geomorphology 134, 344-362. doi:10.1016/j.geomorph.2011.07.010

El Arabi, E.H., Diez, J.B., Broutin, J., Essamoud, R., 2006. Première caractérisation palynologique du Trias moyen dans le Haut Atlas ; implications pour l'initiation du rifting téthysien au Maroc. Comptes Rendus Geosci. 338, 641-649. doi:10.1016/j.crte.2006.04.001

El Arabi, H., Ferrandini, J., Essamoud, R., 2003. Triassic stratigraphy and structural evolution of a rift basin: the Eç Çour basin, High Atlas of Marrakech, Morocco. J. African Earth Sci. 36, 29-39. doi:10.1016/S0899-5362(03)00020-4

El Kochri, A., Chorowicz, J., 1996. Oblique extension in the Jurassic trough of the central and eastern High Atlas. J. Can. Earth Sci. 33, 84-92.

Fabuel-Perez, I., Redfern, J., Hodgetts, D., 2009. Sedimentology of an intra-montane riftcontrolled fluvial dominated succession: The Upper Triassic Oukaimeden Sandstone Formation, Central High Atlas, Morocco. Sediment. Geol. 218, 103-140. doi:10.1016/j.sedgeo.2009.04.006

Frizon de Lamotte, D., Leturmy, P., Missenard, Y., Khomsi, S., Ruiz, G., Saddiqi, O., Guillocheau, F., Michard, A., 2009. Mesozoic and Cenozoic vertical movements in the 
Atlas system (Algeria, Morocco, Tunisia): An overview. Tectonophysics 475, 9-28. doi:10.1016/j.tecto.2008.10.024

Frizon de Lamotte, D., Saint Bezar, B., Bracène, R., 2000. The two main steps of the Atlas building and geodynamics of the western Mediterranean. Tectonics 19, 740-761.

Froitzheim, N., Stets, J., Wurster, P., 1988. Aspects of Western High Atlas tectonics, in: Jacobshagen, V.H. (Ed.), The Atlas System of Morocco. Springer-Verlag, Berlin, pp. 219-244.

Gillcrist, R.M.P., Coward, J.L., Mugnier, X., 1987. Structural inversion and its controls: examples from the Alpine foreland and the French Alps. Geodinamica Acta 1, 5-34.

Hafid, M., Zizi, M., Bally, A.W., Ait Salem, A., 2006. Structural styles of the western onshore and offshore termination of the High Atlas, Morocco. C. R. Geoscience 338, 50-64.

Hailwood, E.A., Mitchell, J.C., 1971. Paleomagnetic and radiometric dating results from Jurassic in south Morocco. R. Astron. Soc. Geophys. J. 24, 351-364.

Hoepffner, C., Soulaimani, A., Piqué, A., 2005. The Moroccan Hercynides. J. African Earth Sci. 43, 144-165.

Hollard, H., 1985. Carte géologique du Maroc-Echelle: 1/1.000.000. Ed. Service Géologique du Maroc, Rabat.

Jenny, J., 1983. Les décrochements de l'Atlas de Demnat (Haut Atlas central, Maroc): prolongation orientale de la zone décrochement du Tizi n'Test et clef de la compréhension de la tectonique atlasique. Eclogae Geol. Helv. 76, 243-251.

Karner, G.D., Gambôa, L.A.P., 2007. Timing and origin of the South Atlantic pre-salt sag basins and their capping evaporites. Geol. Soc. London, Spec. Publ. 285, 15-35. doi:10.1144/SP285.2 
Laville, E., Lesage, J.-L., Seguret, M., 1977. Géométrie, cinématique (dynamique) de la tectonique atlasique sur le versant sud du Haut Atlas marocain. Aperçu sur les tectoniques hercyniennes et tardi-hercyniennes. Bull. Soc. Géol. Fr. (7), t.XIX, 527-539.

Laville, E., Petit, J.-P., 1984. Role of synsedimentary strike-slip faults in the formation of Moroccan Triassic basins. Geology 12, 424-427.

Laville, E., Piqué, A., 1991. La distension crustale atlantique et atlasique au Maroc au début du Mésozoïque: le rejeu des structures hercyniennes. Bull. Soc. Géol. Fr. t. 162, n, $1161-1171$.

Laville, E., Pique, A., Amrhar, M., Charroud, M., 2004. A restatement of the Mesozoic Atlasic Rifting (Morocco). J. African Earth Sci. 38, 145-153.

Manspeizer, W., 1982. Triassic-Liassic basins and climate of the Atlantic passive margins. Geol. Rundschau 71, 895-917.

Manspeizer, W., Puffer, J.H., Cousminer, H.L., 1978. Separation of Morocco and eastern North America: a Triassic-Liassic stratigraphic record. GSA Bulletin 89, 901-920.

Mattauer, M., Proust, F., Tapponnier, P., 1972. Major Strike-slip Fault of Late Hercynian Age in Morocco. Nature 237, 63-72.

Mattauer, M., Tapponnier, P., Proust, F., 1977. Sur les mécanismes de formation des chaînes intracontinentales. L'exemple des chaînes atlasiques du Maroc. Bull. Soc. Géol. Fr. (7), t. $\mathrm{XI}, 521-526$.

Mattis, A.F., 1977. Nonmarine Triassic sedimentation, central High Atlas Mountains, Morocco. J. Sediment. Res. 47, 107-119.

McClay, K.R., Insley, M.W., Anderton, R., 1989. Inversion of the Kechika Trough, Northeastern British Columbia, Canada, in: Geological Society, London, Special Publications. pp. 235-257. doi:10.1144/GSL.SP.1989.044.01.14 
668 669 670 671

Medina, F., 1995. Syn- and postrift evolution of the El Jadida-Agadir basin (Morocco): constraints for the rifting model of the Central Atlantic. Can. J. Earth Sci. 32, 1273-1291.

Michard, A., 1976. Eléments de géologie marocaine. Notes Mémoires du Serv. géologique du Maroc 252, 1-408.

Michard, A., Soulaimani, A., Hoepffner, C., Ouanaimi, H., Baidder, L., Rjimati, E.C., Saddiqi, O., 2010. The South-Western Branch of the Variscan Belt: Evidence from Morocco. Tectonophysics 492, 1-24. doi: 10.1016/j.tecto.2010.05.021

Missenard, Y., Cadoux, A., 2012. Can Moroccan Atlas lithospheric thinning and volcanism be induced by Edge-Driven Convection?. Terra Nova 24, 27-33. doi:10.1111/j.13653121.2011.01033.x

Missenard, Y., Saddiqi, O., Barbarand, J., Leturmy, P., Ruiz, G., El Haimer, F.-Z., Frizon de Lamotte, D., 2008. Cenozoic denudation in the Marrakech High Atlas, Morocco: insight from apatite fission-track thermochronology. Terra Nova 20, 221-228. doi:10.1111/j.1365-3121.2008.00810.x

Missenard, Y., Taki, Z., Frizon de Lamotte, D., Benammi, M., Hafid, M., Leturmy, P., Sébrier, M., 2007. Tectonic styles in the Marrakesh High Atlas (Morocco): The role of heritage and mechanical stratigraphy. J. African Earth Sci. 48, 247-266. doi:10.1016/j.jafrearsci.2007.03.007

Missenard, Y., Zeyen, H., Frizon de Lamotte, D., Leturmy, P., Petit, C., Sébrier, M., Saddiqi, O., 2006. Crustal versus asthenospheric origin of relief of the Atlas Mountains of Morocco. J. Geophys. Res. 111, B03401. doi:10.1029/2005JB003708

Morley, C.K., 2010. Stress re-orientation along zones of weak fabrics in rifts: An explanation for pure extension in "oblique" rift segments?. Earth Planet. Sci. Lett. 297, 667-673. doi:10.1016/j.epsl.2010.07.022 
692

Ouanaimi, H., Petit, J., 1992. La Limite sud de la chaine hercynienne dans le Haut Atlas marocain; reconstitution d'un saillant non deforme. Bull. Soc. Géol. Fr. 163, 63-72.

Petit, J.-P., Beauchamp, J., 1986. Synsedimentary faulting and palaeocurrent patterns in the Triassic sandstones of the High Atlas (Morocco). Sedimentology 33, 817-829.

Pique, A., Michard, A., 1989. Moroccan Hercynides; a synopsis. The Paleozoic sedimentary and tectonic evolution at the northern margin of West Africa. Am. J. Sci. 289, 286-330.

Proust, F., Petit, J.-P., Tapponnier, P., 1977. L'accident du Tizi n'Text et le rôle des décrochements dans la tectonique du Haut Atlas occidental (Maroc). Bull. Soc. Géol. Fr. (7), t. XI, 541-551.

Qarbous, A., Medina, F., Hoepffner, C., 2003. Le bassin de Tizi n'Test (Haut Atlas, Maroc): exemple d'évolution d'un segment oblique au rift de l'Atlantique central au Trias. Can. J. Earth Sci. 40, 949-964. doi:10.1139/E03-029

Qarbous, A., Medina, F., Hoepffner, C., 2008. Tectonique cassante et état de contrainte dans le bassin de Tizi n'Test (Haut Atlas, Maroc) au cours de l'inversion tertiaire. Estud. Geológicos 64, 17-30.

Saura, E., Verges, J., Martin-Martin, J.D., Messager, G., Moragas, M., Razin, P., Grelaud, C., Joussiaume, R., Malaval, M., Homke, S., Hunt, D.W., 2013. Syn- to post-rift diapirism and minibasins of the Central High Atlas (Morocco): the changing face of a mountain belt. J. Geol. Soc. London 171, 97-105. doi:10.1144/jgs2013-079

Schettino, A., Turco, E., 2009. Breakup of Pangaea and plate kinematics of the central Atlantic and Atlas regions. Geophys. J. Int. 178, 1078-1097. doi:10.1111/j.1365246X.2009.04186.X

Stets, J., Wurster, P., 1981. Zur Strukturgeschichte des Hohen Atlas in Marokko. Geol. Rundschau 70, 801-841. 
Stets, J., Wurster, P., 1982. Atlas and Atlantic-Structural Relations, in: V. von Rad M. Sarnthan, E. Seibold, K.H. (Ed.), Geology of the NW African Continental Margin. Springer Verlag Berlin Heidebeas New York 1082, pp. 69-85.

Tari, G., Molnar, J., Ashton, P., Hedley, R., 2000. Salt tectonics in the Atlantic margin of Morocco. Lead. Edge October.

Teixell, A., Arboleya, M.L., Julivert, M., 2003. Tectonic shortening and topography in the central High Atlas. Tectonics 22, 1051. doi:10.1029/2002TC001460

Teixell, A., Ayarza, P., Zeyen, H., Fernàndez, M., Arboleya, M.-L., 2005. Effects of mantle upwelling in a compressional setting: the Atlas Mountains of Morocco. Terra Nova 17, 456-461. doi:10.1111/j.1365-3121.2005.00633.x

Van Houten, F.B., 1977. Triassic-Liassic deposits of Morocco and eastern North America: comparison. AAPG Bulletin 61, 79-99.

Zeyen, H., Ayarza, P., Fernàndez, M., Rimi, A., 2005. Lithospheric structure under the western African-European plate boundary: A transect across the Atlas Mountains and the Gulf of Cadiz. Tectonics 24. doi:10.1029/2004TC001639 
Figure 1. Plate reconstruction of the Central Atlantic to the Triassic-Jurassic boundary (200 Ma) (modified from Schettino and Turco, 2009). Rift zones are shown in dark grey. The square indicates the reconstructed position of the Marrakech High Atlas pf Morocco (MHA).

Figure 2. (a) Geologic map of the western and Marrakech High Atlas (modified from Hollard, 1985), showing location of the study area detailed in (b). (b) Geologic map of the Marrakech High Atlas showing the main structural elements. Squares correspond to areas described in detail in this paper.

Figure 3. Schematic chronostratigraphic diagram showing the main stratigraphic units of the Triassic in the Marrakech High Atlas. The diagram results from a compilation of our data and data from the literature (see text for references). The thickness of the Triassic deposits represented here corresponds to the western part of the Tizi n'Test basin.

Figure 4. Detailed geologic map of the Tirknit-Tizi n'Test Triassic basins in the Axial Zone of the High Atlas, and of the post-rift Cretaceous-Cenozoic deposits of the Sub-Atlas zone north of the Souss basin. See Fig. 2(b) for location.

Figure 5. (a-f) Cross sections across the Tizi n'Test-Tirknit Triassic basins perpendicular to the NE-trending basin-boundary faults. See Fig. 4 for location.

Figure 6. Panoramic and close-up views of different structural elements of the Tizi n'Test and Tirknit basins (see Fig. 4 for location). (a) General view of the Tizi n'Test basin including the southern boundary fault. Compare with sections in fig. $5(\mathrm{~d}, \mathrm{e})$. (b) Close-up of minor normal faults affecting the Upper Siltstone (F6)-basement unconformity preserved in the hanging wall of backthrust VII. Compare with section in Fig. 5(e,f). (c) View of the erosional northern border of the Tizi n'Test Triassic basin showing the Pink Oukaimeden Sandstone (F5b) unconformable on Paleozoic slate. (d) Close-up view (perpendicular to the fault dip) of fault 5, southern border of the Tizi n'Test basin. Note the foliation developed in the Paleozoic slates indicating dip-slip normal shear in this fault. (e) Panoramic view of normal fault 2 and thrust IV. Compare with sections in Fig. 5(b,c). (f) Detailed view of extensional fault zone 2, southern border of the Tirknit basin. Note the foliation developed in the Paleozoic limestone. 
Figure 7. Detailed geologic map and cross sections of the Tizi n'Tacht-Imlil Triassic basin (see location in Fig. 2).

Figure 8. Panoramic and detailed images of different structural elements of the Tizi n'TachtImlil Triassic basin (see Fig. 7 for location). (a) General view of the Tizi n'Tacht basin showing extensional and inversion structures. Compare with section b-b' in figure 7. (b) View of backthrust $\mathrm{X}$. The Paleozoic block on the foreground is separated from the backthrust and the Triassic by a strike-slip cross-fault. (c) Detailed view of normal fault 7 and associated drag folds formed both in the Precambrian and in the Triassic deposits. (d, e) Strike-slip and dip-slip slickenslides observed in fault plane of backthrust X.

Figure 9. Detailed map of the Setti Fadma Triassic outcrop, southern border of the Ourika Triassic basin. See location in Fig. 4.

777 Figure 10: Stereographic projections showing strike, dip and striae direction of major extensional faults (faults 4, 5 and 9) at selected localities which provided a significant number of slickensides. (a-d) faults 4 and 5 southern border of the Tizi n'Test basin (see Fig. 4 for location). (e, f) Ourika fault (fault 9), southern border of the Setti-Fadma graben (location in Fig. 9). (h) Ourika fault (fault 9) locality at $31^{\circ} 17^{\prime} 38.6^{\prime \prime} \mathrm{N}, 7^{\circ} 29^{\prime} 47.2^{\prime \prime} \mathrm{W}$ to the ENE of e,f (18 km out of Fig. 9).

Figure 11: (a) Reconstruction of the Triassic basins of the Marrakech High Atlas to Mid Triassic times, previous to the sedimentation of the Pink Oukaimeden sandstone (F5b), dated as Carnian, and Upper limestone (F6). Paleocurrent data are from Fabuel-Perez et al. (2009) and Petit and Beauchamp (1986). (b) Present-day geologic and tectonic features after the Cenozoic inversion in the High Atlas.

Figure 12: Present-day cross section of the Marrakech High Atlas (see location in Fig. 2) and restoration to a state previous to the orogenic inversion in the Late Cretaceous. 


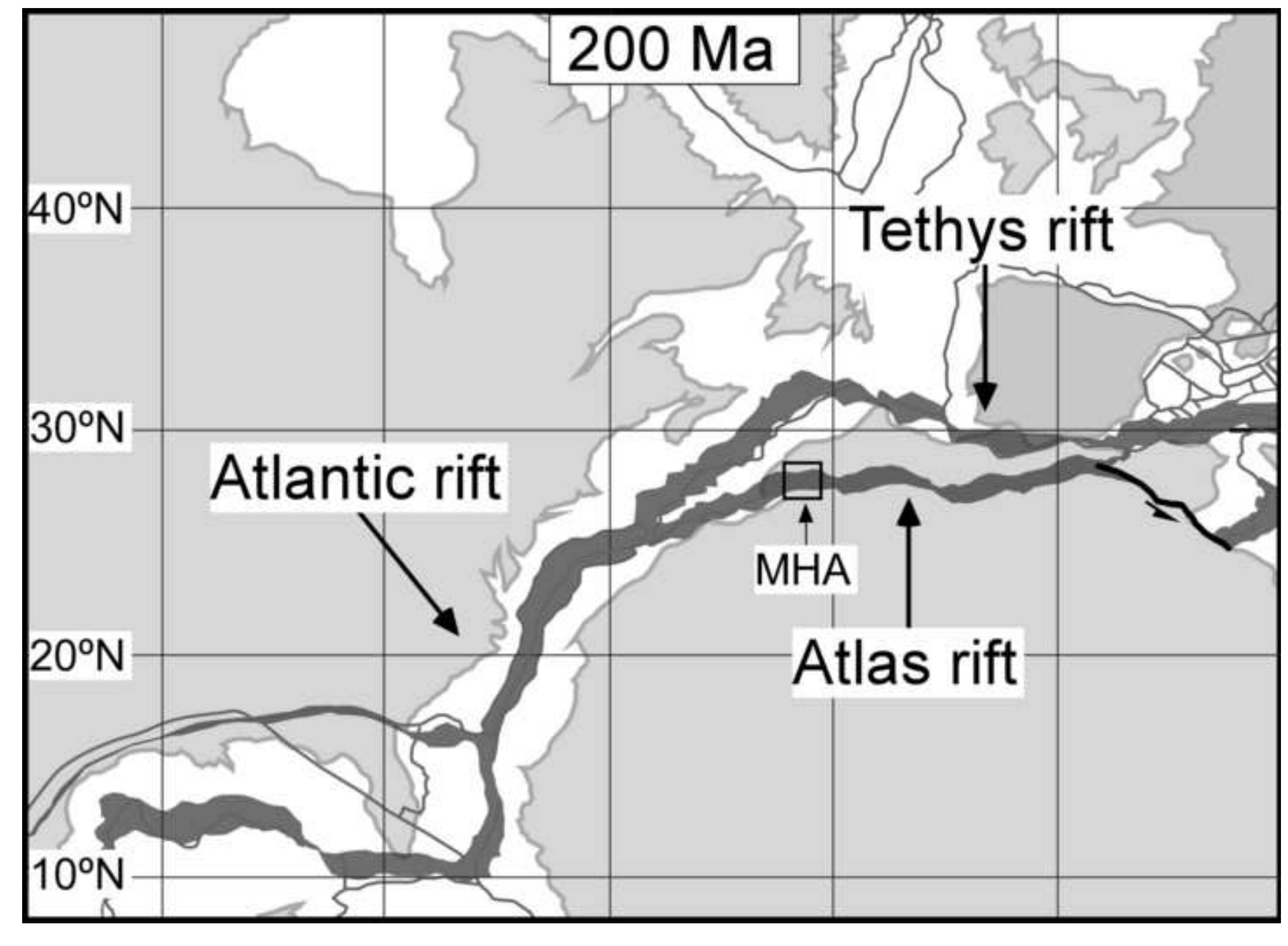




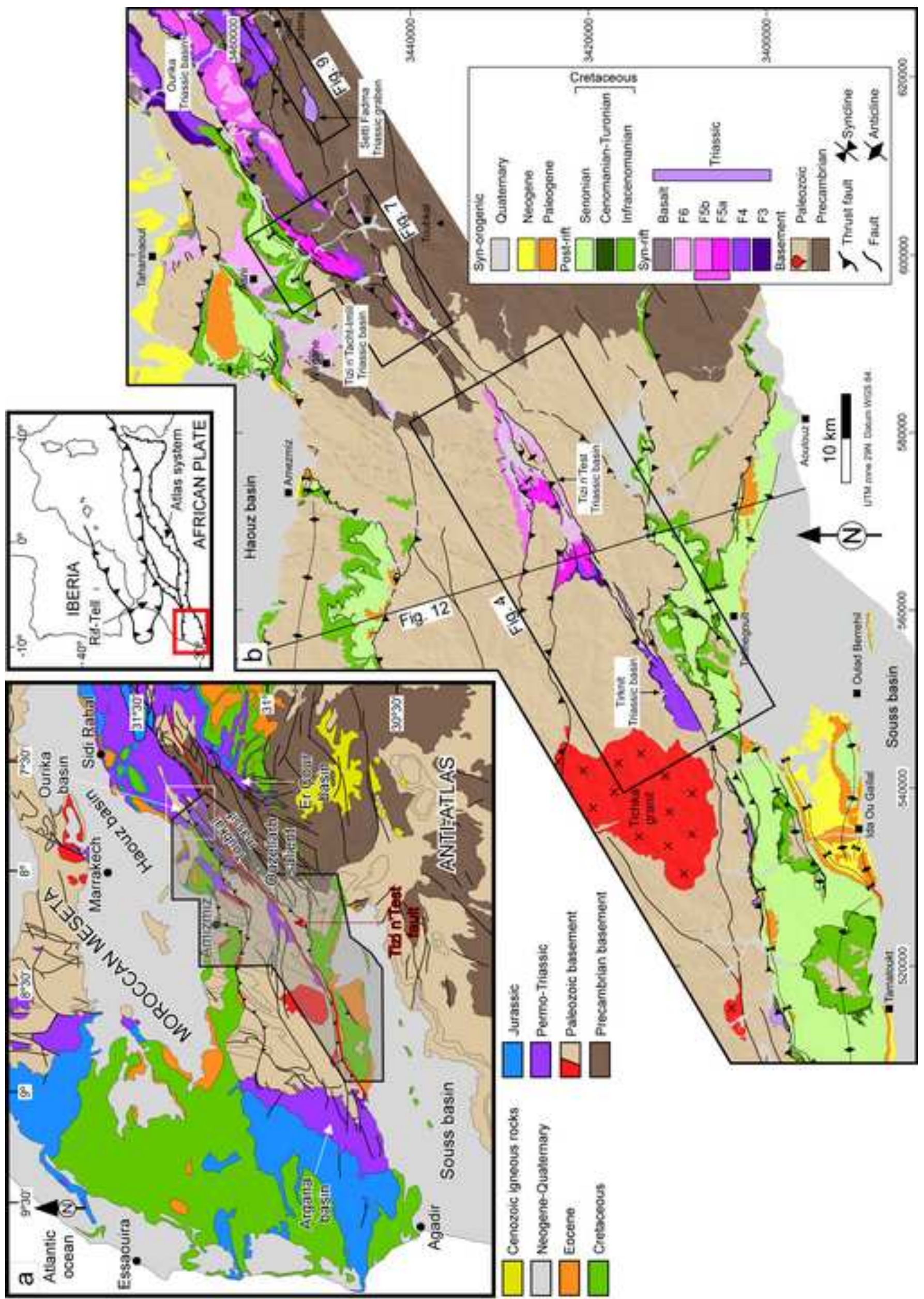




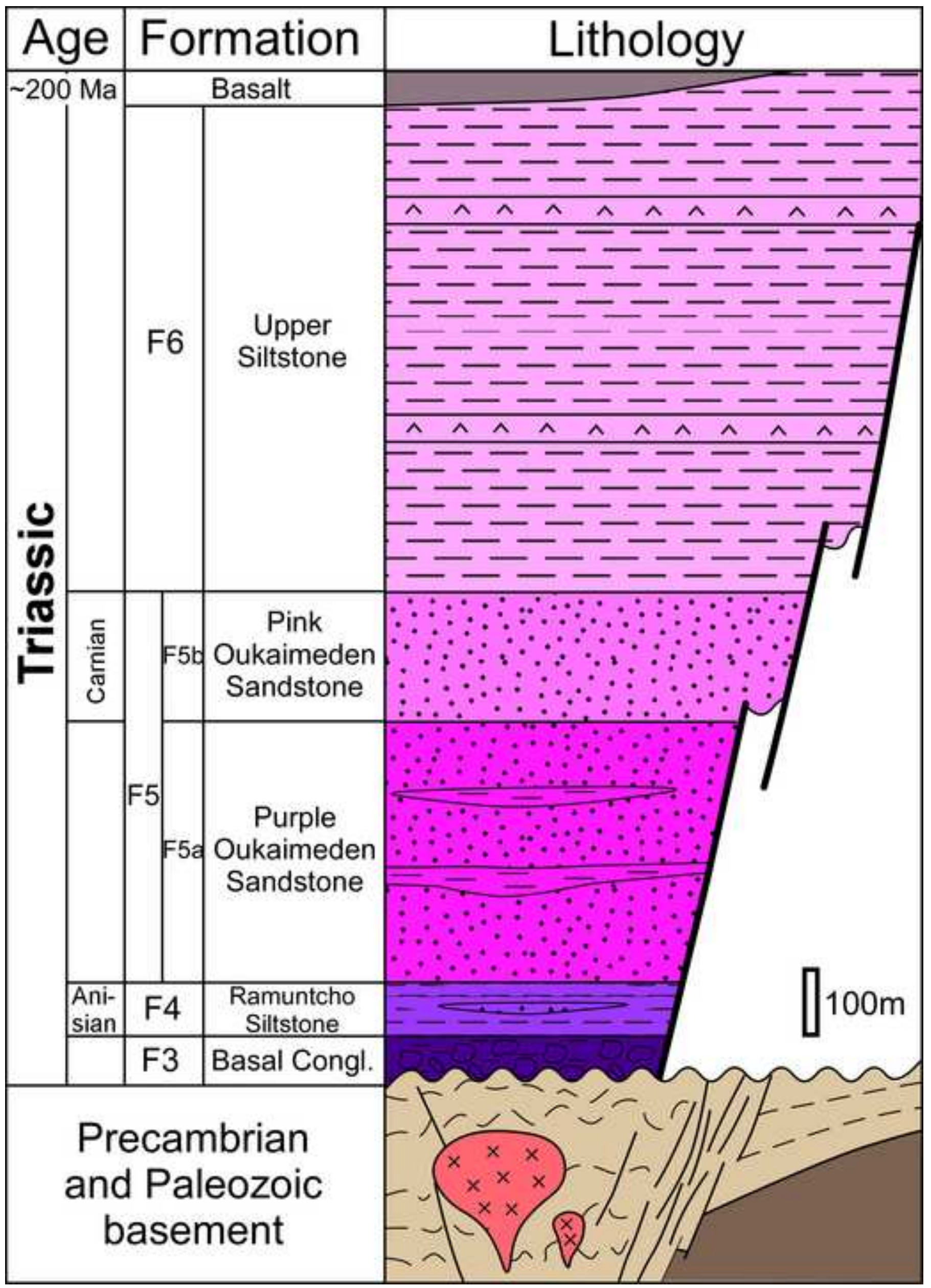


Figure 4. Color. 1.5 column

Click here to download high resolution image

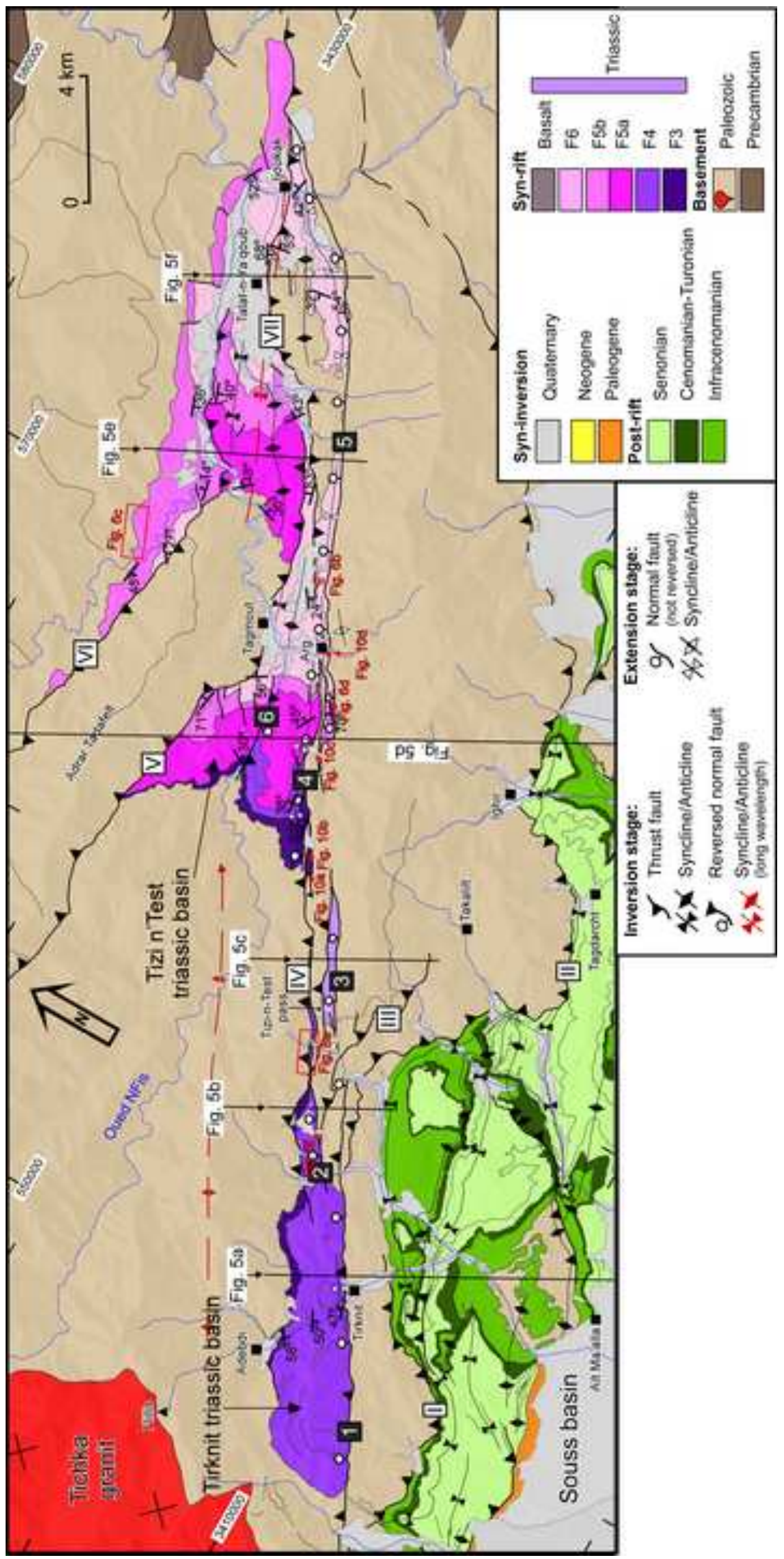




\section{Figure 5. Color. Double column}

Click here to download high resolution image
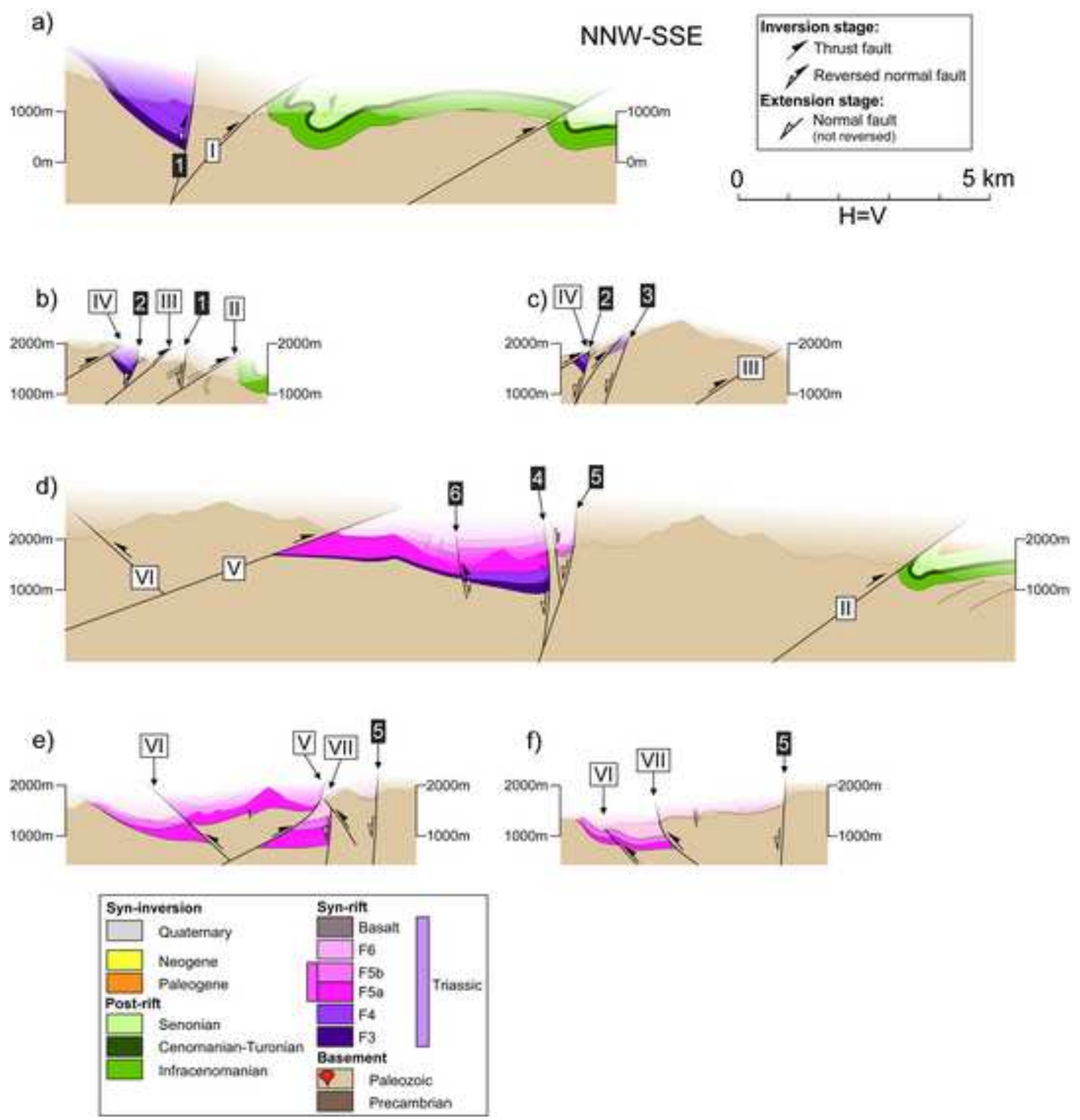
Click here to download high resolution image
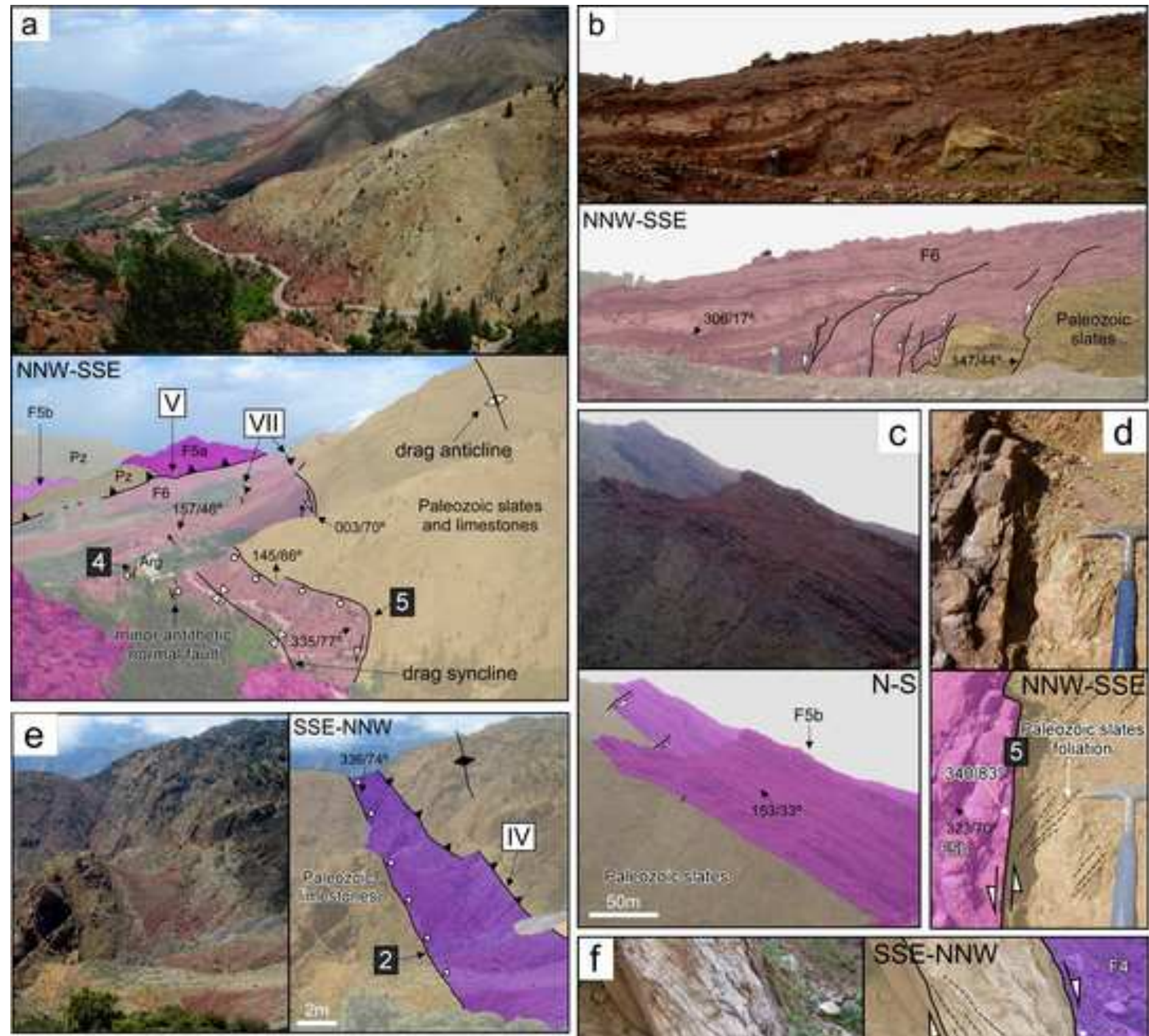

NNW-SSE
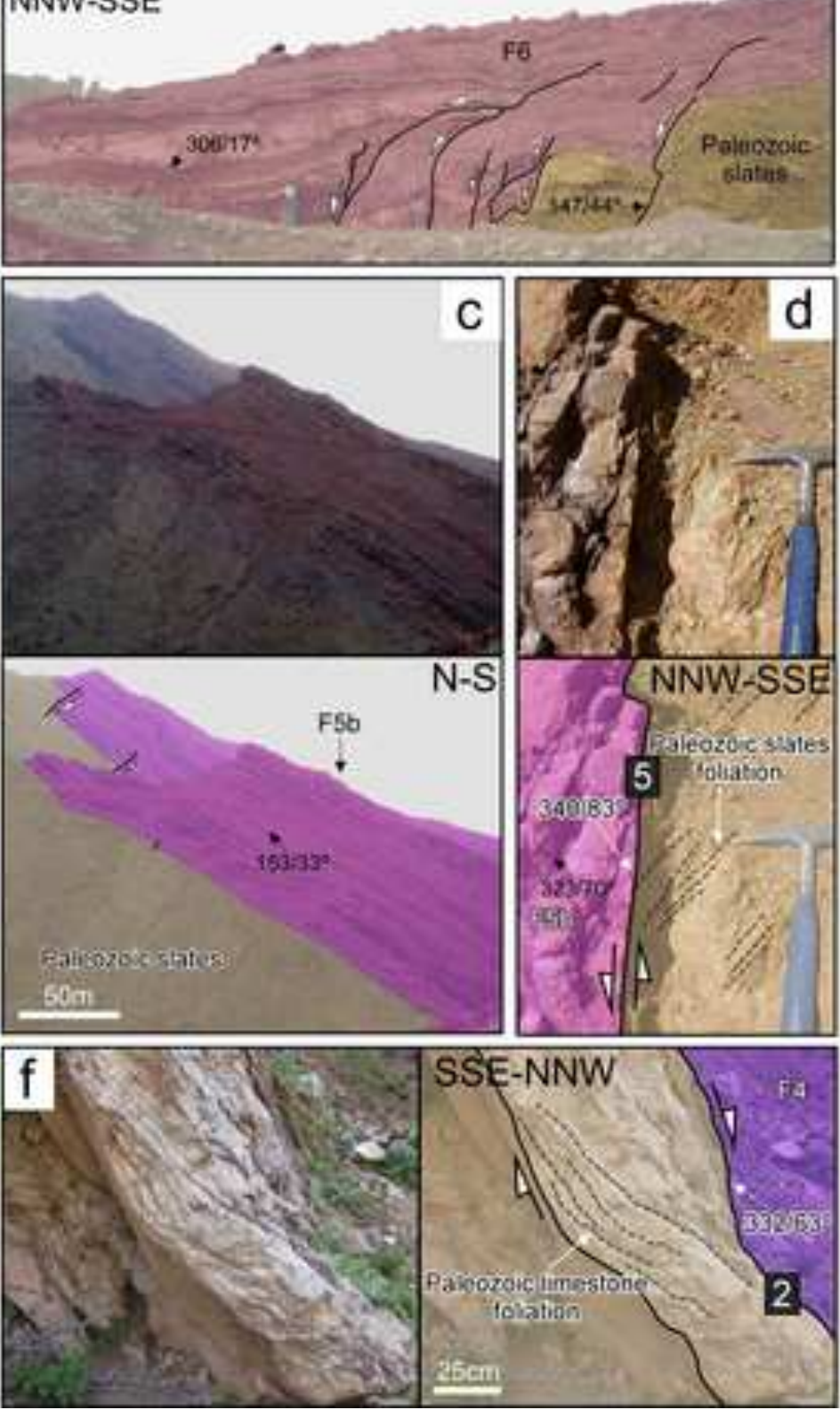
Figure 7. Color. Double column

Click here to download high resolution image
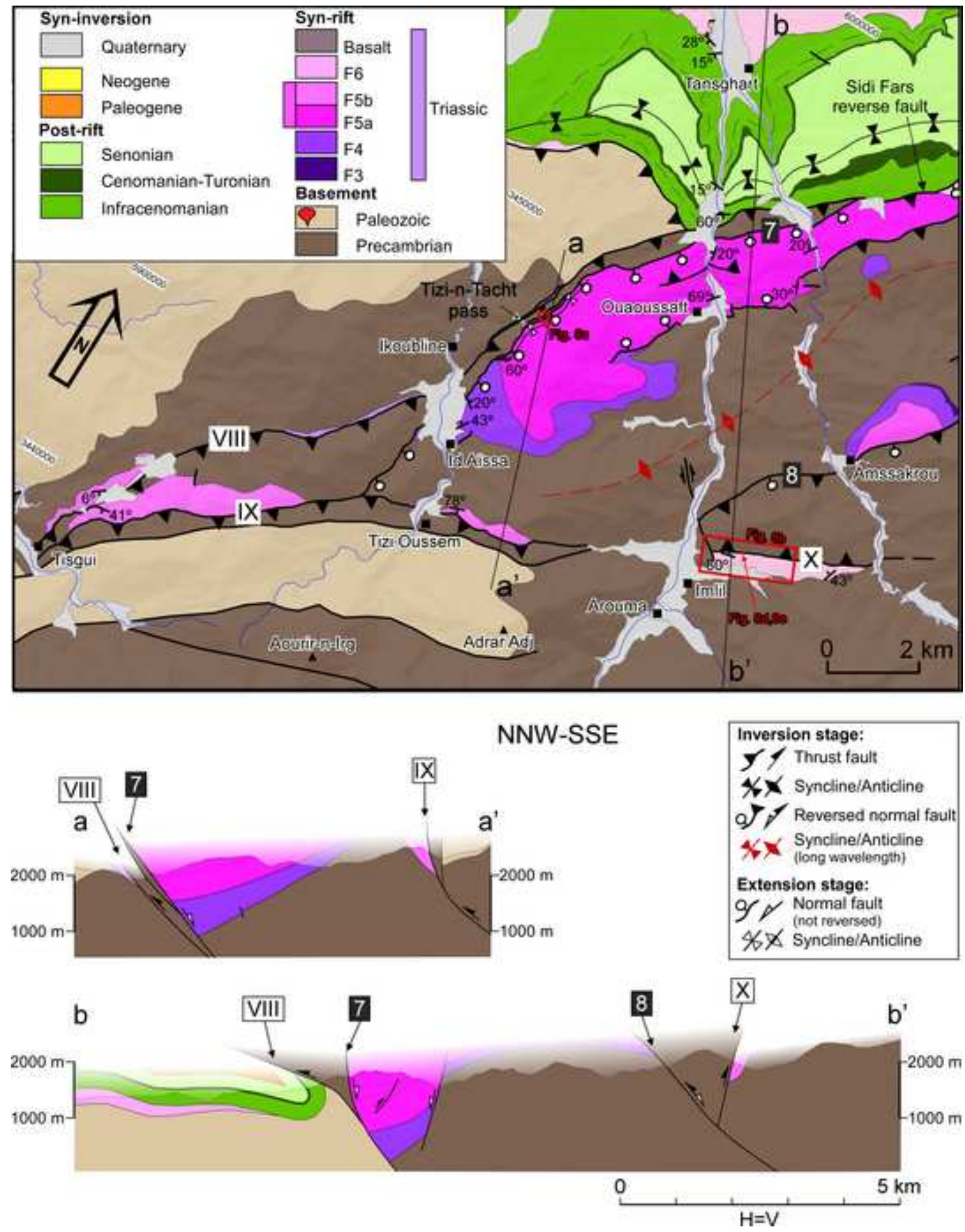

Inversion stage:

$\boldsymbol{y}$ Thrust fault

X) Syncline/Anticline

a) Reversed normal fault

*. Syncline/Anticline

Extension stage:

9 of Normal fault

4/ $\not$ Syncline/Anticline 

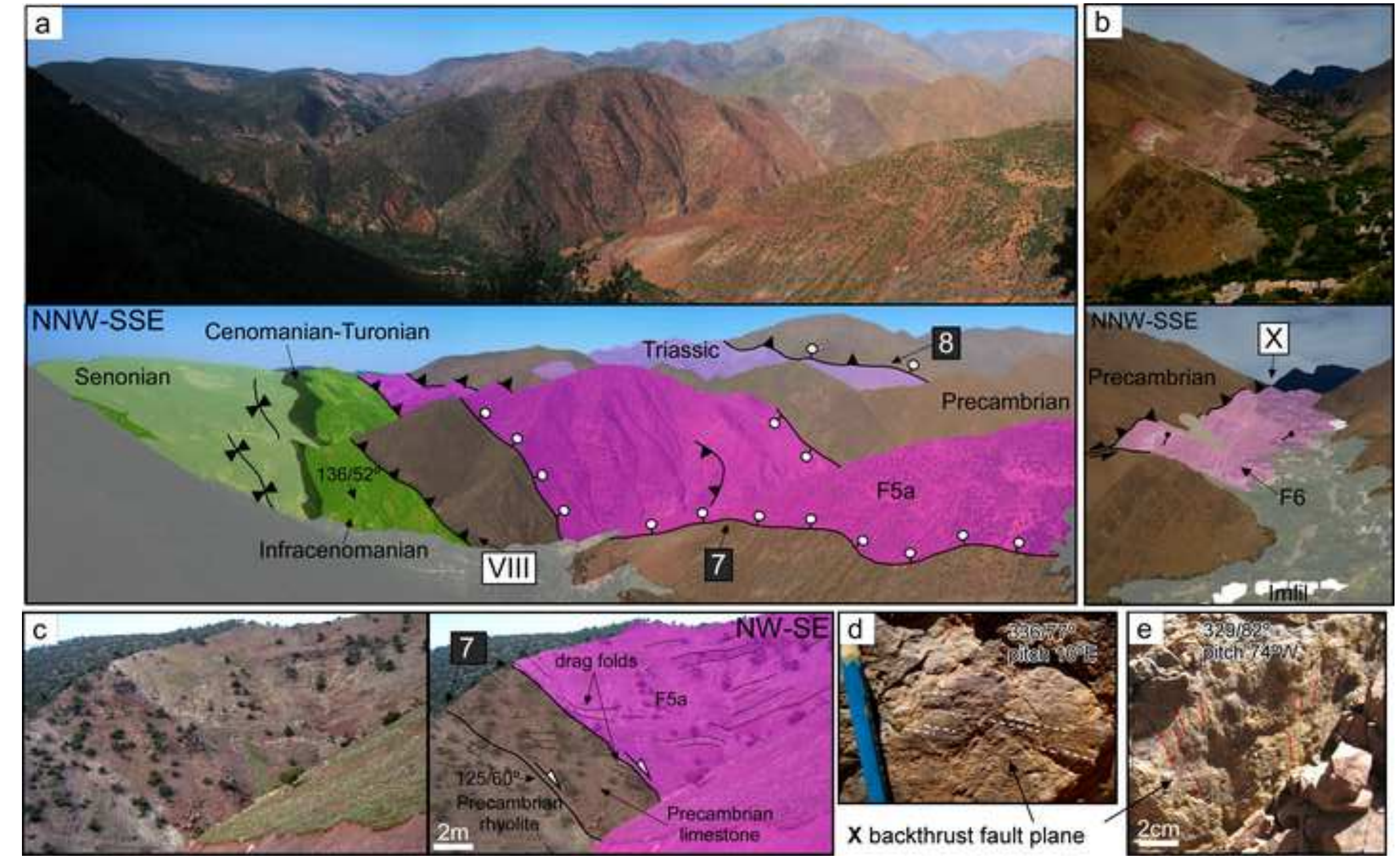

$\mathrm{X}$ backthrust fault plane

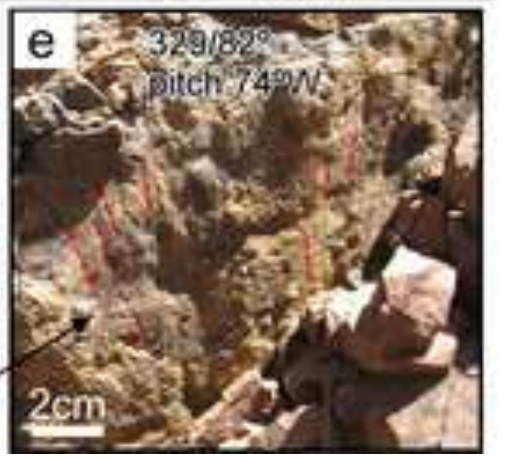




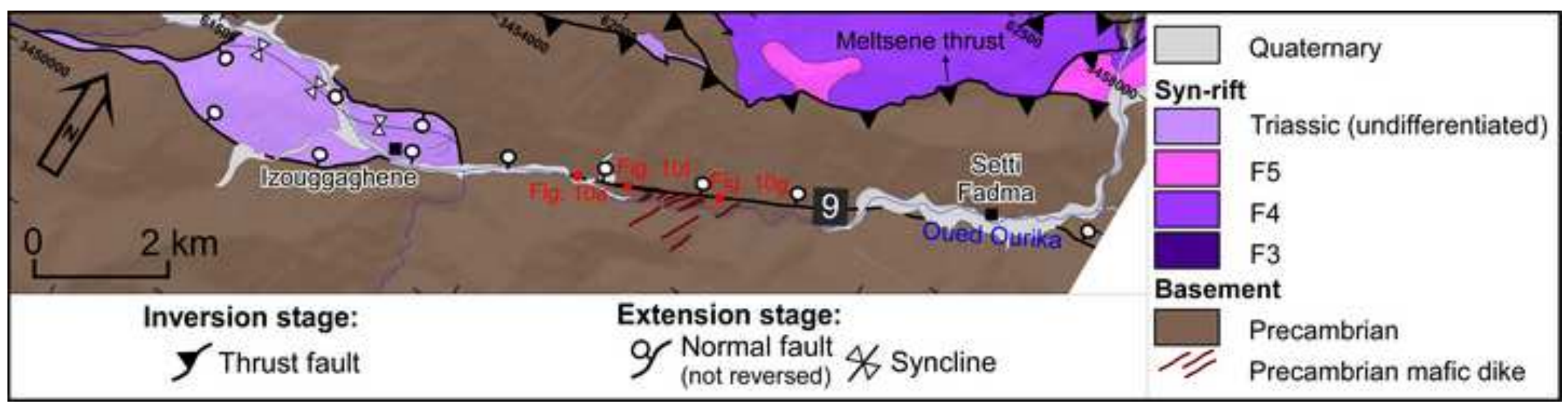


a)

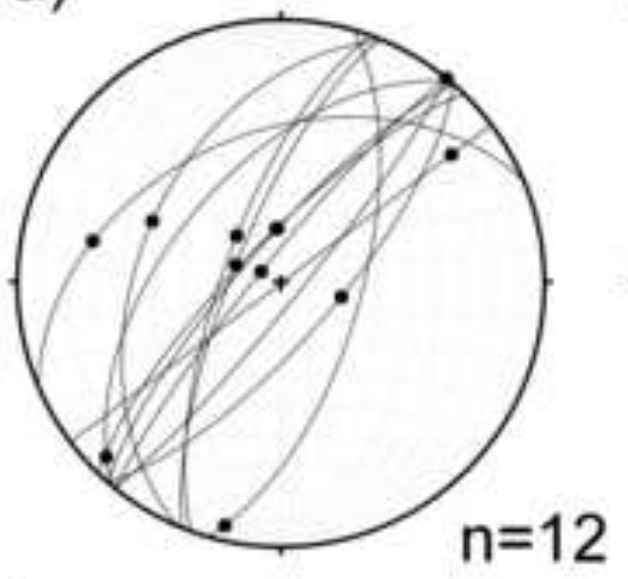

fault 4

e)
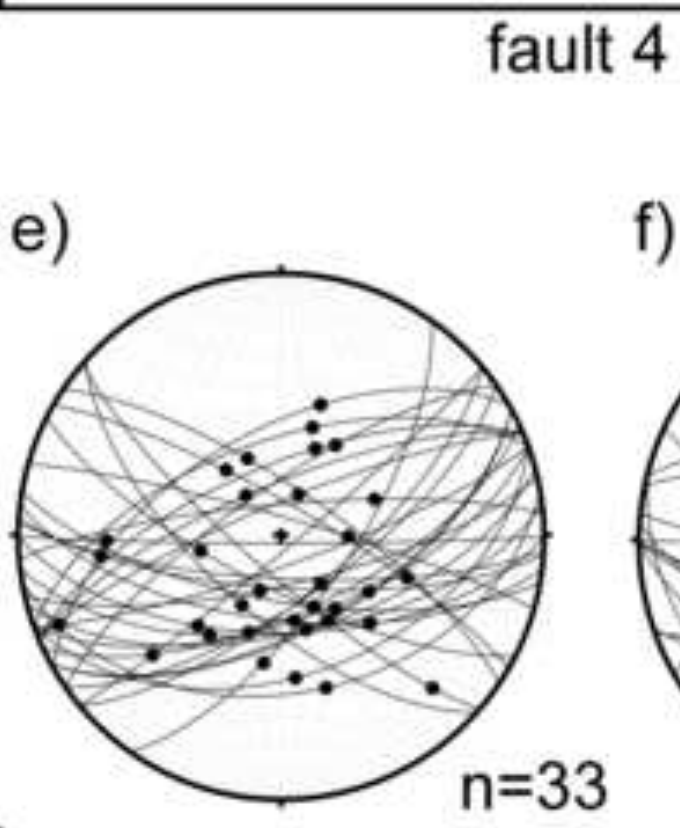

f) b)

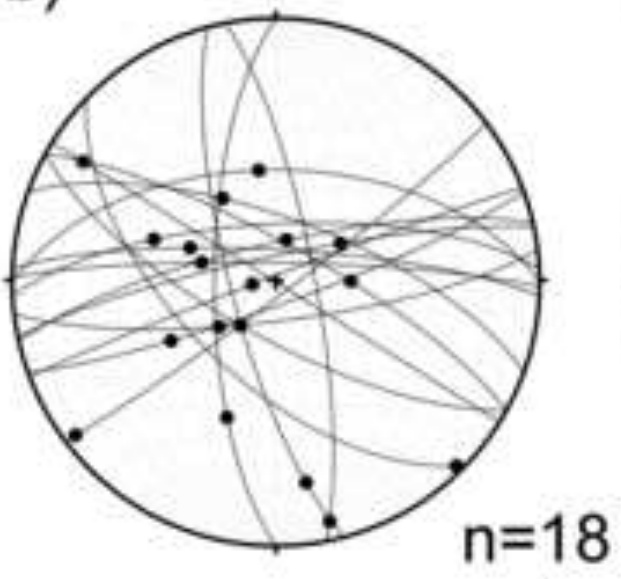

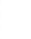

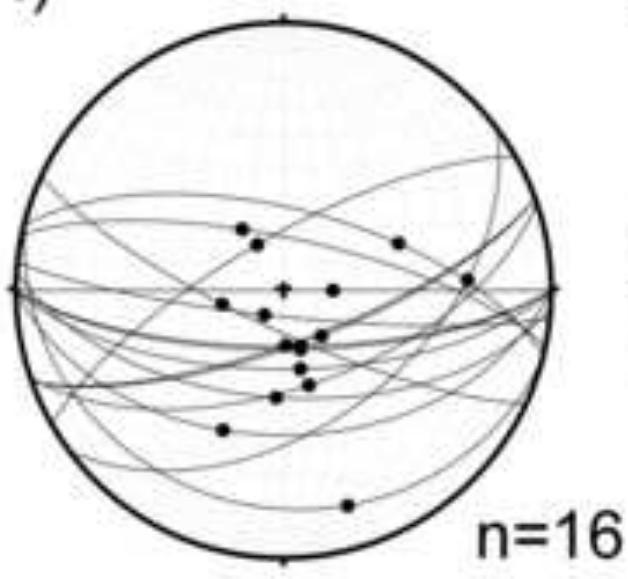

c)

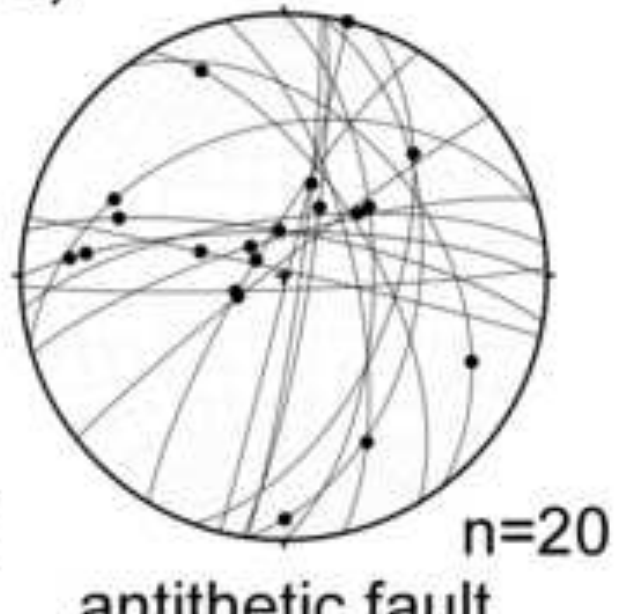

antithetic fault (to fault 4 and 5) d)

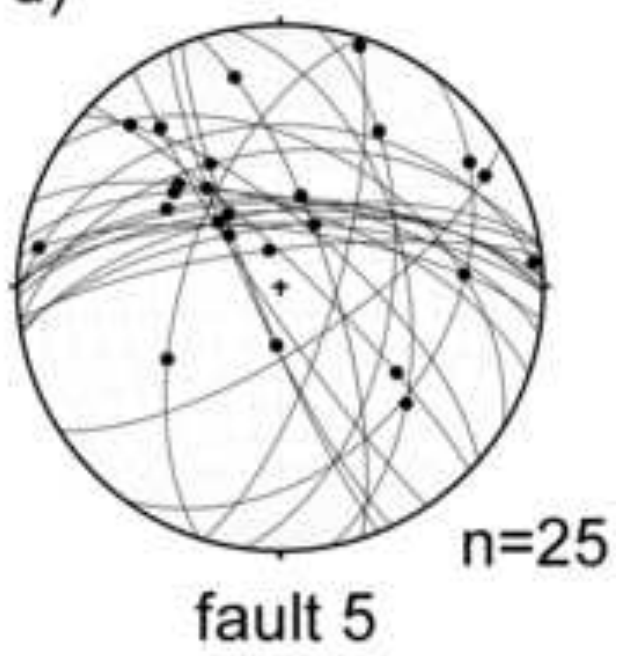

h)
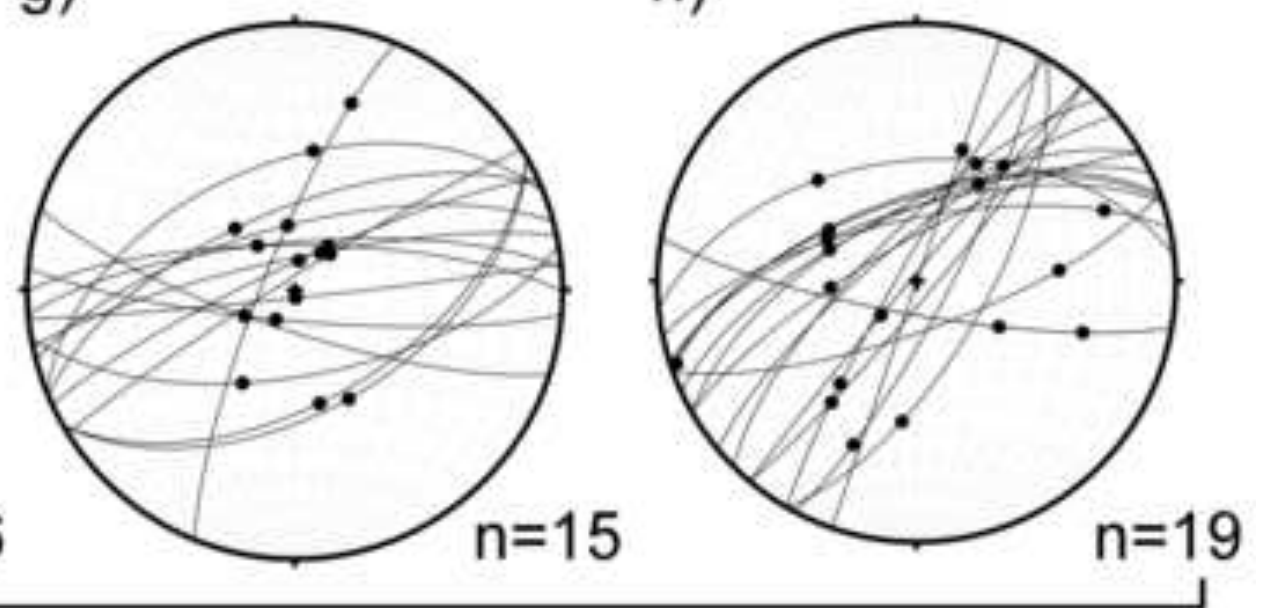

Ourika fault or fault 9 
Figure 11. Color. Double column

Click here to download high resolution image
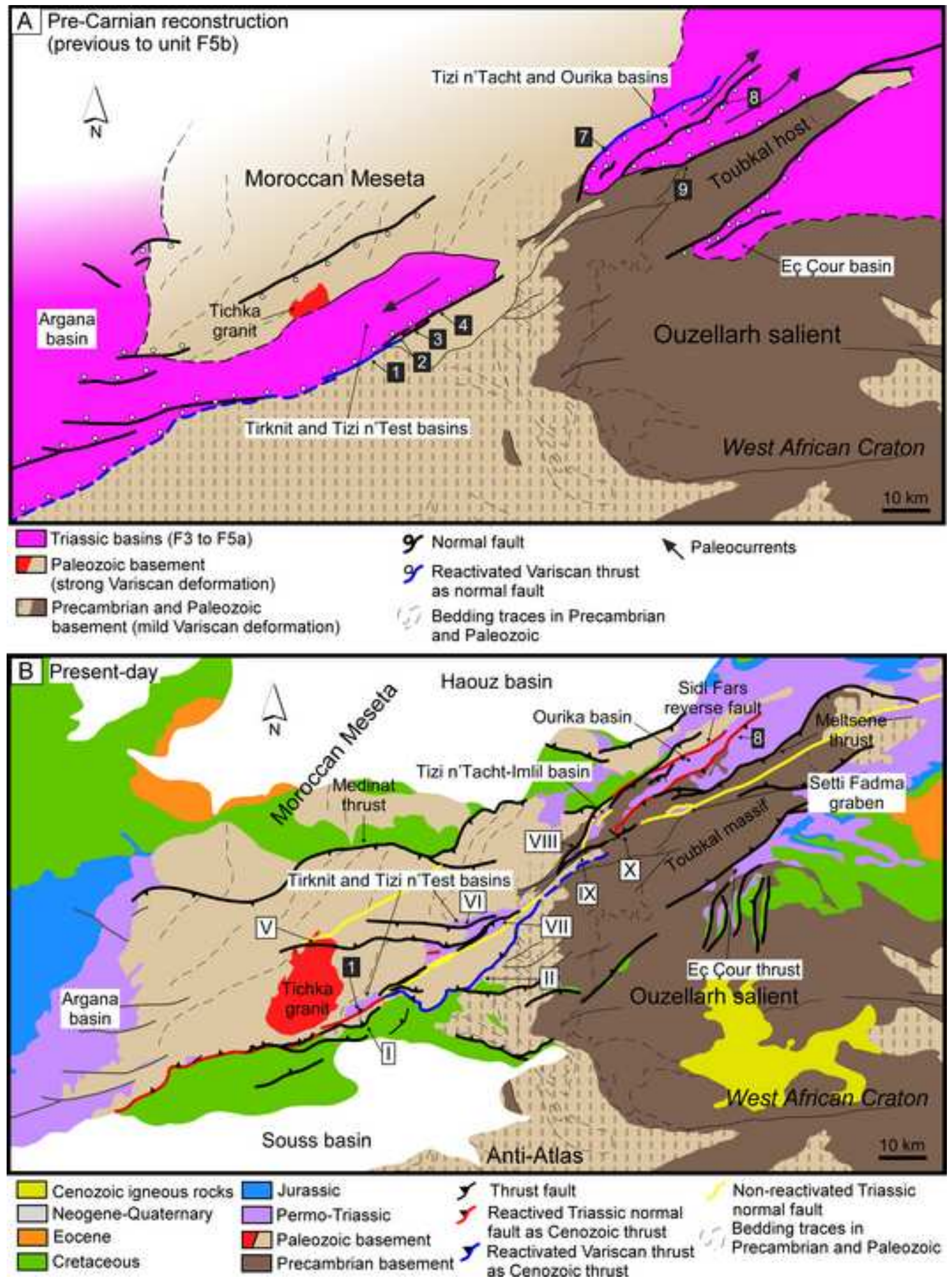
a) Late Cretaceous

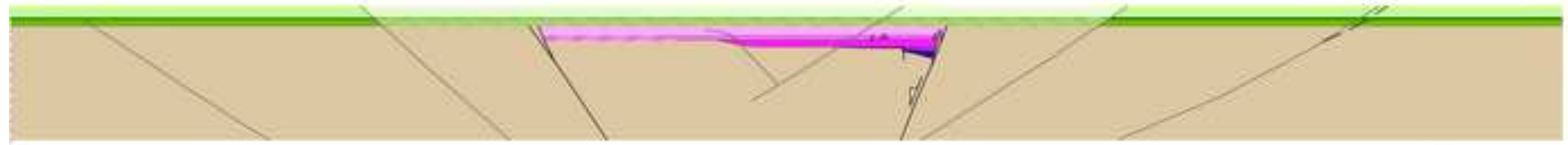

b) Present-day section

$10 \mathrm{Km}$

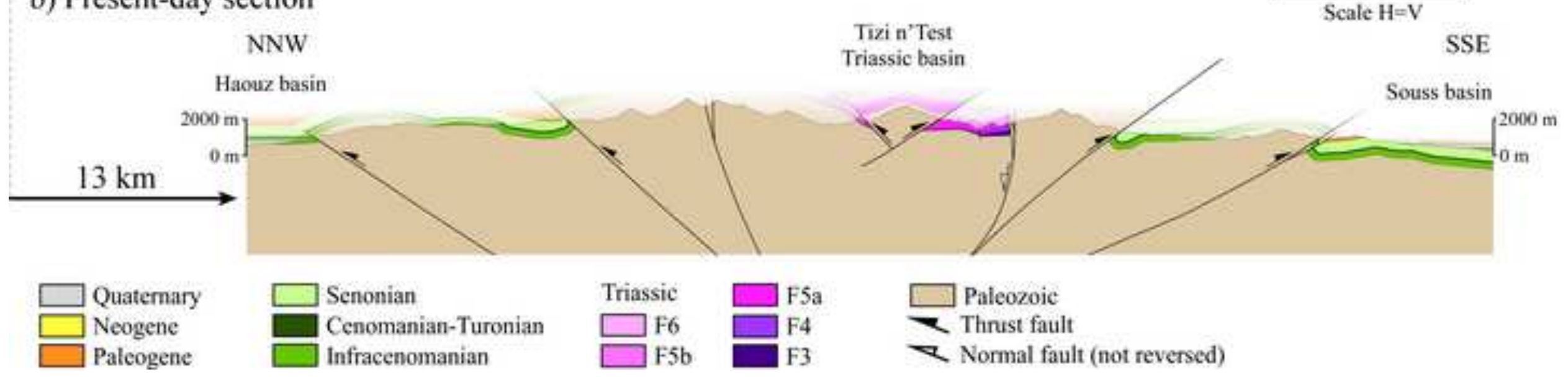

